\title{
Causes and systematics of inundations of the Krasnodar territory on the Russian Black Sea coast
}

\author{
Nikolay Alexeevsky ${ }^{1, \dagger}$, Dmitry V. Magritsky ${ }^{1}$, Klaus Peter Koltermann ${ }^{1}$, Inna Krylenko ${ }^{1,2}$, and Pavel Toropov ${ }^{1,3}$ \\ ${ }^{1}$ Lomonosov Moscow State University, Moscow, Russia \\ ${ }^{2}$ Water Problem Institute, Russian Academy of Sciences, Moscow, Russia \\ ${ }^{3}$ Institute of Geography, Russian Academy of Sciences, Moscow, Russia \\ ${ }^{\dagger}$ Deceased in 2015
}

Correspondence to: Dmitry V. Magritsky (magdima@yandex.ru)

Received: 6 December 2015 - Published in Nat. Hazards Earth Syst. Sci. Discuss.: 30 November 2015

Revised: 3 May 2016 - Accepted: 11 May 2016 - Published: 8 June 2016

\begin{abstract}
The inundation situations on the Black Sea coast of the Krasnodar territory for the period from 1945 until 2013 were analysed and the main types of inundations at the coast are described. Synoptic factors of the formation of extreme precipitation and rainfall floods, features and regularities of the downstream flood wave transformation in the rivers are also studied. Therefore, assessments of seasonal and maximum flow of the Black Sea coast rivers for the period of hydrometric measurements were done. Regularities of change of the occurrence of inundations and their characteristics on the coastal terrain were analysed, for a year and on a perennial timescale.

Most catastrophic and exceptional inundations arise in the summer and in early autumn. Small inundations during the remaining year reflect the seasonal distribution of river flow and floods in the Black Sea rivers. Extensive and sometimes extreme precipitation dominates the river flow regimes. The seasonal distribution of small and moderately dangerous inundations reflects, on average, a water regime of two groups of rivers of the coast - to the north and to the south of the Tuapse River. To the north of the Tuapse River, floods prevail from November until March (up to $70 \%$ of observed floods took place in this period) as a result of precipitation and winter snowmelt during frequent thaw periods. In winter, high waters often overlap to form a multi-peak high water of 2-3 weeks' duration. In the summer and in early autumn we observe a steady low flow. The total amount of runoff increases both in a southeast direction, and with the altitude of the river basins. Interannual variability of mean annual runoff, as well as maximum runoff, on the contrary decreases in the southern
\end{abstract}

direction and with an increasing area of the river basins. The coastal high waters of the rivers of the Sochi part of the coast are typical at any time of the year, but more often floods in the cold season result from incessant rain, and thawing snow. Annually up to 25 floods have been observed. The principal reason of such distribution is the increase of extreme rainfall in the warm season.

Orographic features of the coast and detailed features of rainfall only cover a small number of local river basins and a limited area. The geographical correlation of individual rainfall and subsequent floods ceases to be statistically significant for distances over $40-60 \mathrm{~km}$.

The annual flow cycle is mainly determined by two seasons, winter/spring and summer, with strong and weak flows, respectively; almost $71 \%$ of all catastrophic and exceptional inundations took place in July-August $(71 \%)$ and in October-November (29\%). The characteristic features of dangerous floods are their rapid formation and propagation, a significant increase of water level (up to 5-7 $\mathrm{m}$ and more) and the multiple increase of water discharges in comparison with low flow period.

Analysis of the interannual changes of the number of inundations at the Black Sea coast of the Krasnodar territory has shown some increase of the number of inundations in the period from the early 1970s until the early years of the twenty-first century.

Quantitative assessments of risk, hazard and damage for the population and economic activities from accidental inundations in the valleys of the Black Sea coast rivers show that economic and social losses from inundations at the Black Sea 
coast of the Krasnodar territory are some of the highest in the Russian Federation. The basic conclusion from recent inundations is the need to consider not only the lower reaches and mouths of the Black Sea coast rivers where the main part of the social and economic development of the coast is concentrated, but also whole river basins and catchments. Further, an analysis of the efficiency of the measures applied at the coast to mitigate inundations and their after-effects is provided.

\section{Introduction}

Coasts, valleys and river mouths are often subject to the influence of various dangerous hydrological phenomena. Of all dangerous phenomena, inundations result in the most significant economic and ecological damages, and are the greatest danger to the population. According to numerous data on the inundations in the river mouths and in the coastal zones of the European part of Russia (from the eighteenth to the twentieth century until 2013), collected by the authors of this paper (Alexeevsky et al., 2013), materials of Taratunin (2000) and other sources, the Black Sea coast of the Krasnodar territory is the most effected coastal region in Russia. In this rather small area, there were five catastrophic inundations during the last 10-20 years, which resulted in huge material damages and considerable human loss. Further, nine large and a number of smaller inundations took place. Recent devastating inundations happened in July and August 2012. Inundations on 6-7 July 2012 affected the coast and the northern slopes of the Caucasus (city of Krymsk), and led to the deaths of about 170 people and to material damage of ca. USD 625 million (Alexeevsky et al., 2013; Volosuhin and Tkachenko, 2013).

In general, there is a certain increase in the number and the magnitude of inundations. If it is so, which factors cause this trend? Is it the reaction to global and regional climate changes, the intensification of instabilities of the climate system? What is the effectiveness of the present-day system of inundation forecasts, prevention and of timely warning people about floods danger? Which potential means are available to strengthen this system?

Unfortunately, there are presently no clear answers for too many of these questions, for several principal reasons. First, despite the known significant hydrological hazards, a complex survey of the inundation situation at the Black Sea coast of the Russian Federation has practically not been done until the present day. Many available publications have a narrative character and focus on the description of recent catastrophic inundations and their effects (Vorobyev, 2003; Evsyukov et al., 2013; Ermachkov, 2010; Taratunin, 2000; Tkachenko, 2012). Important elements of scientific analysis are found in some works (Barinov, 2009; Belyakova et al., 2013; Kononova, 2012; Magritsky et al., 2013a, b;
Panov et al., 2012; Sergin et al., 2001; Svanidze et al. 1983; Tkachenko, 2012; Volosuhin and Tkachenko, 2013), in the Atlas of connatural and technogenic dangers and risks of emergencies of the Southern Federal district (2007) and in papers of the Kuban State Agrarian University. Secondly, there is a lack of high-quality data on inundations observed in the past, especially in the twentieth century, on the basic characteristics of inundations (areas submerged, their spatial extent, the intensity of their development and duration, depths of flooding, water levels and discharges) and information on the amount and the structure of the estimated damage. Thirdly, it is the lack of necessary details and reliable long series of observational data. Hydrological monitoring is not available for all rivers of the coast. The frequency of observations is normally twice a day, and in official hydrological directories the data are published, in general, averaged over 1 day, whereas high waters form and pass within some hours. Hydrological gauge stations only have short time series of observations. Many stations have been discontinued; there are practically no rivers with several gauging stations along their course. Moreover, in view of the complex orography and particular spatial and temporal features of precipitation, the observations at meteorological stations are not always representative, even for adjacent river basins. Meteorological radars at the coast were not available until recently.

The lack of necessary data for detailed research and better understanding of factors and fundamental physics of the flood phenomenon and knowledge of key parameters is probably one of the reasons for the inefficiency of measures applied at the coast to cope with inundations and their effects. The data collected by the authors and results of our long-term research of the inundation problem, quantitative, graphic and cartographical interpretations of available information allows the gap in knowledge to now be filled, and new research to be initiated.

\section{Study area}

The Black Sea coast of the Krasnodar territory of the Russian Federation includes the Temryuk and Tuapse administrative areas (districts), and the cities of Novorossiysk, Anapa, Gelendzhik and Sochi (Fig. 1). These cities also are the main administrative districts by their area, proportion of the developed and undeveloped territories. The total area of the coast is nearly $8015 \mathrm{~km}^{2}$. As a relatively narrow strip of land (its average width is $23 \mathrm{~km}$ ) the coast extends over $350 \mathrm{~km}$ (from the Kerch Strait to the Psou River). The land border of the Black Sea coast coincides with the watershed line between the basins of the Azov and Black seas.

The coastal terrain is well developed. Over 1.1 million people live here constantly. About $90 \%$ of the resident population is concentrated in a narrow strip with a width from 0.5 to $8 \mathrm{~km}$ and $80 \%$ live in cities and urban settlements (Magritsky et al., 2013a; Data of Federal State Statistics Service 
Table 1. Average water discharges and season distribution of water flow of the rivers of the Black Sea coast of the Krasnodar territory.

\begin{tabular}{|c|c|c|c|c|c|c|c|c|}
\hline \multirow[t]{2}{*}{$\begin{array}{l}\text { River, } \\
\text { gauging station }\end{array}$} & \multirow[t]{2}{*}{$\begin{array}{l}\text { The basin } \\
\text { area, } \mathrm{km}^{2}\end{array}$} & \multirow{2}{*}{$\begin{array}{l}\text { Average } \\
\text { altitude of } \\
\text { basin, } m\end{array}$} & \multirow[t]{2}{*}{$\begin{array}{l}\text { The period of } \\
\text { observation }\end{array}$} & \multirow{2}{*}{$\begin{array}{l}\text { Average water } \\
\text { discharge }\left(\mathrm{m}^{3} \mathrm{~s}^{-1}\right)^{(1)} / \\
\text { variation coefficient }\end{array}$} & \multicolumn{4}{|c|}{$\begin{array}{c}\text { Season distribution of water flow } \\
(\%)\end{array}$} \\
\hline & & & & & Spring & Summer & Autumn & Winter \\
\hline $\begin{array}{l}\text { Gostagayka, } \\
\text { Gostagaevskaya }\end{array}$ & 106 & 160 & $\begin{array}{l}\text { 1949-2000, } \\
2009-2011\end{array}$ & $0.36 / 0.59$ & 39.8 & 10.8 & 6.2 & 43.2 \\
\hline $\begin{array}{l}\text { Dyurso, } \\
\text { Abrau-Dyurso }\end{array}$ & 51.9 & 190 & 1948-1976 & $0.47 / 0.36$ & 32.3 & 7.2 & 6.3 & 54.2 \\
\hline Mezyb, Vozrozhdenie & 100 & - & 1983-1994 & $2.0 /-$ & - & - & - & - \\
\hline Aderba, Sveltyi & 57.4 & 250 & $\begin{array}{l}1966-1993, \\
1996-1997\end{array}$ & $0.94 / 0.36$ & 32.5 & 7.6 & 7.7 & 52.2 \\
\hline $\begin{array}{l}\text { Vulan, } \\
\text { Arkhipo-Osipovka }\end{array}$ & 265 & 240 & $\begin{array}{l}\text { 1948-2006, } \\
\text { 2009-2011 }\end{array}$ & $5.71 / 0.36$ & 28.5 & 8.3 & 9.5 & 53.7 \\
\hline $\begin{array}{l}\text { Tuapse, } \\
\text { Tuapse }\end{array}$ & 351 & 390 & $\begin{array}{l}1938-1942, \\
1944,1945, \\
1949-1996, \\
2009-2010\end{array}$ & $13.1 / 0.30$ & 28.3 & 7.0 & 18.0 & 46.7 \\
\hline Ashe, Ashe & 282 & 570 & $\begin{array}{l}1956-1982 \\
1984-1991\end{array}$ & $14.3 / 0.29$ & 30.5 & 9.3 & 18.9 & 41.3 \\
\hline $\begin{array}{l}\text { Kuapse, } \\
\text { Mamedov Shchel }\end{array}$ & 14.6 & 380 & $\begin{array}{l}\text { 1946-1991, } \\
1993,1994, \\
1996-2011\end{array}$ & $0.74 / 0.35$ & 31.5 & 9.9 & 16.78 & 41.9 \\
\hline Psezuapse, Tatyanovka & 255 & 760 & 1955-1992 & $14.4 / 0.20$ & 35.0 & 11.2 & 17.9 & 35.9 \\
\hline $\begin{array}{l}\text { Shakhe, } \\
\text { Soloh-aul }\end{array}$ & 423 & 1010 & $\begin{array}{l}1926-1991, \\
1993-1994, \\
1998-2001, \\
2003-2011\end{array}$ & $28.4 / 0.22$ & 39.7 & 16.3 & 18.0 & 26.0 \\
\hline Psiy, Tuh-aul & 20.4 & 700 & 1946-1988 & $1.20 / 0.20$ & 34.6 & 12.4 & 17.6 & 35.4 \\
\hline $\begin{array}{l}\text { West Dagomys, } \\
\text { Dagomys }\end{array}$ & 49.0 & - & $\begin{array}{l}\text { 1974-1994, } \\
1996-2003, \\
2004-2011\end{array}$ & $2.43 / 0.27$ & 29.5 & 10.2 & 22.0 & 38.3 \\
\hline Sochi, Plastunka & 238 & 840 & $1927-2011$ & $15.2 / 0.22$ & 38.2 & 15.6 & 18.8 & 27.4 \\
\hline Sochi, Sochi & 296 & 720 & 1945-2012 & $16.5 / 0.21$ & 37.1 & 14.4 & 18.8 & 29.7 \\
\hline Khosta, Khosta & 98.5 & 480 & $\begin{array}{l}\text { 1927-1994, } \\
1997-2011\end{array}$ & $5.06 / 0.20$ & 31.2 & 14.4 & 19.8 & 34.6 \\
\hline $\begin{array}{l}\text { Mzymta, } \\
\text { Krasnaya Polyana }\end{array}$ & 510 & 1670 & $\begin{array}{l}1945-1994, \\
1996-2002, \\
2010-2012\end{array}$ & $34.5 / 0.16$ & 36.9 & 33.7 & 16.6 & 12.8 \\
\hline $\begin{array}{l}\text { Mzymta, } \\
\text { Kazachiy Brod }\end{array}$ & 839 & 1340 & 1967-2012 & $54.5 / 0.18$ & 36.4 & 26.4 & 18.7 & 18.5 \\
\hline
\end{tabular}

(1) Data at some stations extended to longer period of observations;

(2) corrected for a negative shift.

in Krasnodar region). Big cities are Anapa, Novorossiysk, Gelendzhik, Tuapse, Sochi and Adler. It is the largest recreational region of Russia and a fast-developing cluster of various sports (in 2014 the XXIIth Olympic winter games took place in Sochi), as well as a large new business and cultural centre. The number of tourists per year in the region is about 7 million (Berlin and Petrov, 2015); most of the tourist industry is concentrated in the municipal districts along the sea coast.

This region is an important agricultural area of Russia, with a large centre of petroleum refining, production of building materials, transfer of dry and liquid goods and transportation of natural gas and oil products. The important seaports of Gelezny Rog, Novorossiysk and Tuapse are also here.
The Black Sea coast is not homogeneous by its constitution, composition and environment (Panov et al., 2012; Sergin et al., 2001; Resourses, 1969). These distinctions define the specificity of the dangerous natural phenomena in the coastal areas by their kind and hierarchy, and by their impact regarding their development in terms of real or potential damages. A contrasting topographical relief and geological constitution, the irregular distribution of atmospheric precipitation mainly creates their heterogeneity. Under hydrological aspects, the Black Sea coast is an isolated basin structured by numerous basins of small rivers. From the Krasnodar territory, 252 watercourses flow into the Black Sea; only $16 \%$ have a length of more than $10 \mathrm{~km}$ (Resources, 1969). Only three rivers (the Shakhe, Mzymta and Psou) have a length of more than $50 \mathrm{~km}$ and a drainage area above $400 \mathrm{~km}^{2}$ (Fig. 1). 
Table 2. Maximum water discharges of the rivers of the Black Sea coast.

\begin{tabular}{|c|c|c|c|c|c|c|c|c|}
\hline \multirow[t]{2}{*}{ River, gauging station } & \multirow[t]{2}{*}{ The period of observation } & \multicolumn{3}{|c|}{ Peak water discharge $\left(Q_{\max }\right), \mathrm{m}^{3} \mathrm{~s}^{-1}$} & \multicolumn{4}{|c|}{$\begin{array}{l}\text { Water discharges, } \mathrm{m}^{3} \mathrm{~s}^{-1} \text {, } \\
\text { and their probability }(2)\end{array}$} \\
\hline & & $\begin{array}{l}\text { Medium } \\
Q_{\max }\end{array}$ & $\begin{array}{l}\text { Coefficient } \\
\text { of } \\
\text { variation }^{(1)}\end{array}$ & Max. $Q_{\max } \mathrm{yr}^{-1}$ & $1 \%$ & $2 \%$ & $5 \%$ & $10 \%$ \\
\hline $\begin{array}{l}\text { Gostagayka, } \\
\text { Gostagaevskaya }\end{array}$ & $\begin{array}{l}1949-2000, \\
2009-2011\end{array}$ & 12.9 & 0.84 & $43.8 / 1966$ & 53 & 44 & 34 & 27 \\
\hline $\begin{array}{l}\text { Dyurso, } \\
\text { Abrau-Dyurso }\end{array}$ & 1948-1976 & 16.5 & 0.65 & $38.3 / 1967$ & 49 & 44 & 37 & 31 \\
\hline Aderba, Sveltyi & 1966-1993, 1996-1997 & 63.1 & 0.82 & $178 / 1981$ & 240 & 207 & 165 & 130 \\
\hline $\begin{array}{l}\text { Vulan, } \\
\text { Arkhipo-Osipovka }\end{array}$ & $\begin{array}{l}\text { 1948-2006, } \\
\text { 2009-2011 }\end{array}$ & 367 & 0.50 & $1050 / 1980$ & 1030 & 870 & 700 & 580 \\
\hline $\begin{array}{l}\text { Tuapse, } \\
\text { Tuapse }\end{array}$ & $\begin{array}{l}1938-1942,1944,1945 \\
1949-1996,2009-2010\end{array}$ & 450 & 0.90 & $2300 / 1991$ & 2330 & 1790 & 1100 & 660 \\
\hline Ashe, Ashe & $\begin{array}{l}1956-1982 \\
1984-1991\end{array}$ & 325 & 0.72 & $1435 / 1991$ & 1340 & 1070 & 750 & 535 \\
\hline $\begin{array}{l}\text { Kuapse, } \\
\text { Mamedov Shchel }\end{array}$ & $\begin{array}{l}\text { 1946-1991, 1993, } \\
1994,1996-2011\end{array}$ & 34.1 & 0.62 & $115 / 1991$ & 125 & 105 & 81 & 63 \\
\hline Psezuapse, Tatyanovka & $1955-1992$ & 320 & 0.59 & $1200 / 1991$ & 1010 & 830 & 645 & 525 \\
\hline $\begin{array}{l}\text { Shakhe, } \\
\text { Soloh-aul }\end{array}$ & $\begin{array}{l}\text { 1926-1991, } \\
\text { 1993-1994, } \\
\text { 1998-2001, 2003-2011 }\end{array}$ & 275 & 0.50 & $938 / 1982$ & 905 & 750 & 555 & 435 \\
\hline Psiy, Tuh-aul & $1946-1988$ & 28.3 & 0.62 & $88.7 / 1956$ & 93 & 80 & 62 & 49 \\
\hline $\begin{array}{l}\text { West Dagomys, } \\
\text { Dagomys }\end{array}$ & $\begin{array}{l}\text { 1974-1994, 1996-2003, } \\
\text { 2004-2011 }\end{array}$ & 140 & 0.79 & $511 / 1997$ & 565 & 480 & 355 & 265 \\
\hline Sochi, Plastunka & $1927-2011$ & 282 & 0.45 & $719 / 1997$ & 715 & 625 & 515 & 440 \\
\hline Sochi, Sochi & $1945-2012$ & 355 & 0.50 & $990 / 1997$ & 975 & 860 & 710 & 590 \\
\hline Khosta, Khosta & 1927-1994, 1997-2011 & 175 & 0.51 & $458 / 2002$ & 485 & 420 & 345 & 287 \\
\hline $\begin{array}{l}\text { Mzymta, } \\
\text { Krasnaya Polyana }\end{array}$ & $\begin{array}{l}1945-1994,1996-2002,2010- \\
2012\end{array}$ & 176 & 0.34 & $360 / 1997$ & 365 & 330 & 287 & 253 \\
\hline $\begin{array}{l}\text { Mzymta, } \\
\text { Kazachiy Brod }\end{array}$ & 1967-2012 & 360 & 0.38 & $730 / 2003$ & 800 & 720 & 615 & 535 \\
\hline
\end{tabular}

(1) corrected for a negative shift;

(2) based on probabilities distribution by Kritsky-Menkel and Pearson of type III.

The drainage density increases in the southeast direction from $0.3-0.5$ (and less) to $1 \mathrm{~km}^{-2}$. A large water slope characterizes almost all the streams. On separate reaches, they look like mountain streams with waterfalls. The floodplain is intermittent and narrow, and usually not developed in the upper reaches and in gorges. On the seaside part, numerous alluvial cones occupy the bottom of river valleys.

Total water resources of the rivers of the Black Sea coast are $7.0-7.5 \mathrm{~km}^{3} \mathrm{yr}^{-1}$, or about $2 \%$ of the total river flow into the Black Sea. The total amount of runoff increases both in a southeast direction, and with the altitude of the river basins. Interannual variability of mean annual runoff, as well as maximum runoff, on the contrary decreases in the southern direction and with increasing area of a river basin (Tables 1 and 2). Reductions of runoff due to economic activities are largest on the rivers of the cities of Anapa and Novorossiysk, i.e. in arid and foothill watersheds. Within these terrains, there are many ponds intercepting a part of river water, and agricultural areas demanding an artificial irrigation. Significant water use practices take place also in the basin of the river Mzymta, mainly hydroelectric engineering, and agricultural, industrial and municipal water consumption. The majority of settlements from Novorossiysk to Sochi are supplied with water, pumped from the thick alluvial depositions under the river channels.

Extensive and sometimes extreme precipitation dominates the river flow regimes. Therefore, maximum water levels and discharges can be observed in any month of a year. To the north from the Tuapse, river floods prevail from November until March (to $70 \%$ ). They result from precipitation and winter snowmelt during frequent thaw periods. High waters in the cold season of the year often overlap with each other, forming a multipeak high water with 2-3 weeks in duration. In the summer and in early autumn a steady low flow is observed (Fig. 1). During this period, even rather large rivers can dry up on separate reaches for several days and even several months. Occasionally the low flow is interrupted by high waters caused by heavy rain. In total, 10-13 flood waves per year happen on average. The annual flow cycle mainly determines the inter-seasonal distribution of water flow; for winter and spring, we find about $82-86 \%$ of annual runoff, and at the Tuapse River $-75 \%$ (Table 1, Fig. 1). 


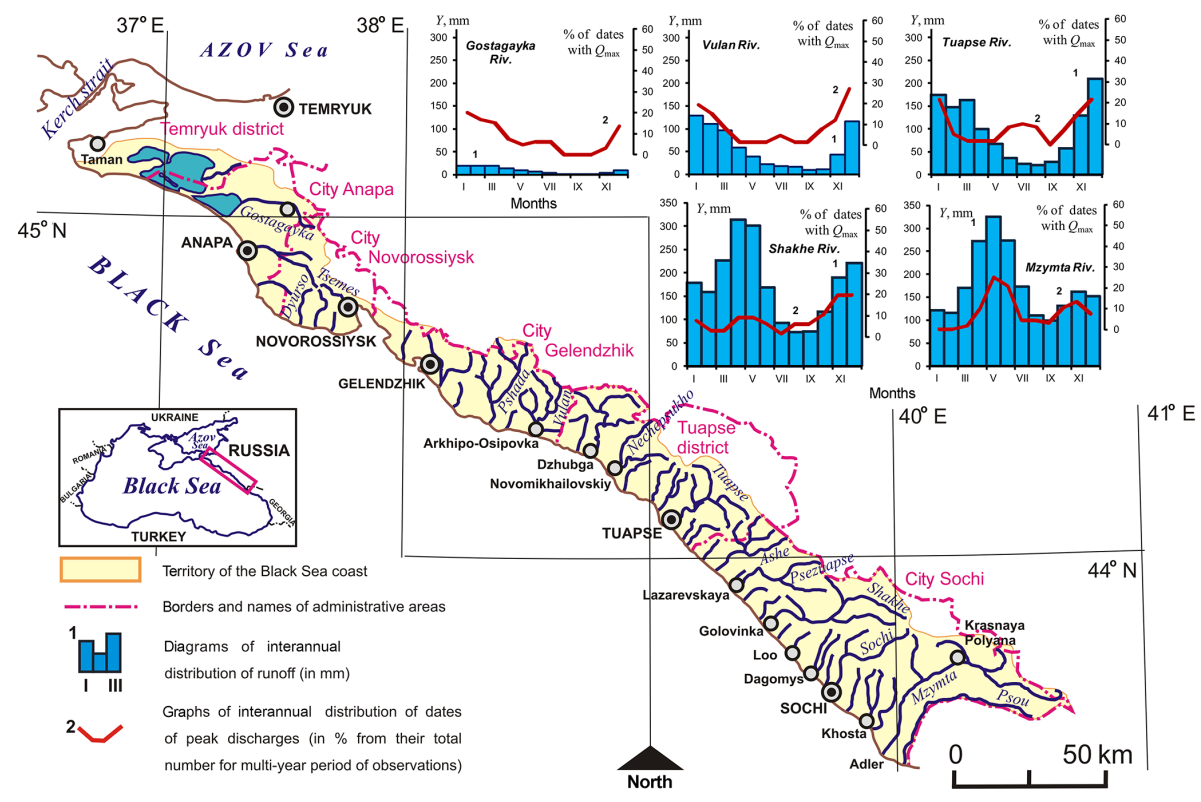

Figure 1. Hydrology of the Black Sea coast of the Krasnodar territory of the Russian Federation and the water regime of the rivers.

The high waters of the rivers of the Sochi district are typical at any time of the year, but more often floods in the cold season result from incessant rain and thawing snow. The river basins of the Shakhe, Sochi and Psou, which have significant areas and altitudes, demonstrate a similarity of spring high water; but only the Mzymta River has a welldistinguished spring-and-summer high water - from March until August (Fig. 1). It is formed by the melting of the seasonal snow cover, the permanent high-mountain snow cover and of snow-patches, glaciers and rain. The duration of the low flow period is shorter compared to the rivers to the north of the Tuapse River, and in general, the river discharges are higher in this period because they are frequently interrupted by floods. Annually up to 25 floods have been observed (on the average 16-20). Moving from the northern to the southern borders of the Sochi part of the coast (Table 1) the percentage of the winter-spring season river flow decreases from 75 to $55-65 \%$.

Floods are typical also for small, in fact, temporary water streams in very narrow valleys (the local people named them "clefts"). Their surface flow only rises in the season of rainfall and (or) snowmelt. Absence of water in the channels of such riverbeds during the main part of the year generates the deceptive opinion about hydrological safety at the bottom of their valleys. Therefore, adverse consequences of inundations here quite often acquire the features of catastrophic events.

\section{Hydrological data and methods of research}

Long-term observation data at 24 hydrological gauging stations of the Federal Hydrometeorology and Environmental Monitoring Service (Table 1) form the data basis for our research. Firstly, the data are presented as average (diurnal, 10-day diurnal, monthly and annual) water levels and water discharges. Data about momentary maximum, minimum water discharges and water levels are also included in this database. Secondly, numerous documentary data on inundations are collected. These data are part of information from the electronic database, Inundations in the river mouths of the European part of Russia, described in Alexeevsky et al. (2013) which is available on the website of the Natural Risk Assessment Laboratory (NRAL) of Moscow State University (http://www.nral.org). Thirdly, we used critical marks of the height of water levels which, when exceeded, lead to flooding of floodplains ( $\left.H_{\text {floodplain }}\right)$, to unfavourable $\left(H_{\mathrm{UP}}\right)$ and dangerous $\left(H_{\mathrm{DP}}\right)$ effects for the population and economic activities. They have unique values at each separate reach of a river channels. Fourthly, we took into account daily precipitation data at six meteorological stations (Sochi, Krasnaya Polyana, Tuapse, Dzhubga, Gelendzhik and Anapa) for the period 1945-2013, and used regional criteria of the level of intensity and potential danger of precipitation. According to these criteria (http://www.yugmeteo.donpac.ru/oj.jsp), rainfall in the Tuapse and Sochi districts with an intensity of not less than $50 \mathrm{~mm}$ (during no more than $1 \mathrm{~h}$ ) are considered as heavy. Rainfall levels of not less than $80 \mathrm{~mm}$ (during no more than $12 \mathrm{~h}$ ) on the part of the coast from Anapa to the settlement Dzhubga, $100 \mathrm{~mm}$ for the Tuapse district and $120 \mathrm{~mm}$ for Sochi are considered as very heavy. In mountain areas, 
the lower limit of very heavy rainfall values is reduced to $50 \mathrm{~mm}$ (Tuapse district) and $80 \mathrm{~mm}$ (Sochi).

Additionally we used the following:

1. field data collected by the research projects of the Geographical Faculty of Moscow State University (the authors of the present paper) from 2011 to 2014;

2. the data of continuous monitoring (time interval of 1$10 \mathrm{~min}$ ) of water level at 53 gauges of the automated system of water level monitoring of the flood control system on the rivers of the Krasnodar territory since 2012 (http://test.emercit.com/overall.html);

3. actual and archived data of various departments and organizations, large-scale maps and charts and data from Internet sources.

These data confirm past inundations at the Black Sea coast of the Russian Federation. We compared the documented events of inundations to maximum water levels $\left(H_{\max }\right)$ and peak discharges $\left(Q_{\max }\right)$ at the gauges with critical high-rise marks $H_{\text {floodplain }}, H_{\mathrm{UP}}, H_{\mathrm{DP}}$, together with daily totals of precipitation at meteorological stations. The critical values (or ranges of values) for these hydrometeorological characteristics have been defined. Based on these results and long-term series (for the period 1945-2013) of hydrometeorological characteristics, all probable cases of river inundations in the past have been determined. The new documented events, which have not been used in research before, have confirmed the applicability of this method.

Part of the statistical analysis (verification of significance of linear trends using parametric and nonparametric tests for the significance level $\alpha=5 \%$, the spectral analysis of the data time series, studying the regression relationship between the magnitude of the inundation and the scale of material damage, etc.) has been performed with the programme STATISTICA 10 (company StatSoft).

The collected materials and their analysis have first allowed inundations on the Black Sea coast of the Krasnodar territory to be classified by their causes, and, second, the territory under consideration and its rivers, as well as the existing (in Russia) classifications of inundations by magnitude and after-effects, to be adapted for.

\section{Inundations and their types}

Inundation in the Russian Federation is perceived as flooding by water of an area adjoining the river or a water body, which leads to material damage, loss of health of the population or to loss of human lives (Nezhihovsky, 1988). More expanded and with an ecological component of the interpretation of this concept, Dobrovolsky and Istomina (2006) suggest the following: "inundation is a temporary flooding of terrain developed by the human for various purposes, generating negative consequences of social and economic and ecological character expressed in a material and non-material damage". On the contrary, flooding by water of undeveloped terrains, not accompanied by damage, is considered as the natural hydrological process accompanying one of the standard phases of a water regime of a river - spring high water or a flood. It is not considered as inundation.

Taking the formation processes and following the new classification, stated by Alexeevsky and Magritsky (2013), at the coast there are some types of inundations. River-flow inundations dominate. At the coast they are generated by high rainfall floods (i.e. during peak discharges and without backwater effect), which sometimes are transformed into mudflow type. More infrequently, they are induced by an intensive snowmelt in the drainage basins (including the contribution of rain), breakages of dams of ponds and glacial lakes. The floodplains of river valleys and river mouths with alluvial cones are also subject to flooding by river waters.

Inundations of river flow and rainfall origin (mixed type no. 1) are next in order of their occurrence. In general, purely rainfall inundations, which also are frequent at the coast, are caused by heavy rainfall over the developed areas and by the inability of the terrain to quickly absorb or drain rainwater into surface and underground water bodies. The magnitude of rainfall inundations increases if storm drains function badly; therefore in their most obvious and dangerous form, they happen in settlements, and their frequency increases with the increase of the area of the urbanized terrains. That is why they are also named urban inundations. In the basins of mountain and foothill rivers, heavy rainfall first leads to rapidly developing flooding by powerful overland streams formed by rainfall waters and by waters of "revived" temporary watercourses. Secondly, rainfall induces high and fast-moving river floods, which are accompanied by river-flow inundations within the same settlements. The same cause and synchronization of these inundations, the difficulties in division zones, flooding by river and rainfall waters and the corresponding damages, as well as lack of data, do not allow these events to be considered separately. They are named inundations of mixed type no. 1 . These inundations not only affect floodplains, but also river terraces and sides of the river valley.

The next type of inundations are the inundations due to storm surges and wind-wave collapse. If flood in a river coincides with a storm surge at the coast, i.e. in conditions of a back-water effect from a sea, inundations of mixed type no. 2 occur. These inundations are possible in river mouths at the coast. They are part of a group of coastal inundations.

Other types of inundations (due to ice-jam formations or tsunami) only represent a potentially small danger to the city of Anapa (Magritsky et al., 2013a, b).

Inundations of one generic type differ by their characteristics (frequency, the area of flooding and the number of the river basins affected by inflow, height and duration of flooding, etc.), and also by size and structure of social and economic damage. The authors do not consider elaborat- 
ing new approaches concerning such a differentiation. Classifications already existing in Russia (Dobrovolsky and Istomina, 2006; Dobroumov and Tumanovsky, 2002; Malik, 2003; Nezhihovsky, 1988; Taratutin et al., 2011) have been used, including those used by the Ministry of Civil Defence and Emergency Situations of the Russian Federation. Accordingly, the river-flow inundations and inundations of the mixed type no. 1 at the Black Sea coast of the Krasnodar territory - the subject of this study - can be divided into small (I), moderately dangerous (II), big (III), catastrophic (IV) and exceptional (V). This classification is based on various qualitative and quantitative criteria. The most important are the frequency of floods, the value of the $H_{\max }$ excess over critical high-rise marks, the area of terrain and the number of the settlements (or basins) covered by the influence of inundations, the amount of direct material damage (as a rule at an approximate assessment) and the threat to lives. Among other criteria, we considered the following: (1) the character of direct damage to industrial objects and road infrastructure and residential buildings, (2) the area and structure of flooding of the developed terrain, (3) the degree of infringement of way of life and industrial activity of people, (4) the necessity of evacuation of people and (5) the deterioration of ecological conditions. Unfortunately, as is often the case, comparable data are not available for all the events. In general, for a separately considered river on the Black Sea coast, the big inundations occur with a frequency $Q_{\max }$ with an average of $4-5 \%$, catastrophic events and exceptional ones $<2-2.5 \%$ and $<1 \%$ respectively.

\section{Synoptic conditions of the formation of high floods}

High floods leading to river-flow inundations, and also flooding by rainfall waters and by overland streams, are formed by the availability of large volumes of water in form of abundant and steady precipitation, by storm rain and, as a special case, as a result of the destruction of waterspouts over the land. Most catastrophic inundations are a consequence of mesoscale atmospheric processes arising in typical synoptic conditions that form especially powerful overcast. For the Black Sea coast of the Krasnodar territory, the formation of abnormal precipitation results from the topographical relief forcing the air upward and, hence, the process of cloud formation and precipitation.

To analyse the dynamics of the atmospheric circulation one can use circulation indices. Among the most well-known are the North Atlantic Oscillation (NAO) index, the East Atlantic/West Russia (EA/WR index) and the Scandinavian pattern (SCAND index). These indices are useful in the analysis of large-scale circulation pattern using results from numerical modelling. For a detailed analysis of the synoptic situation, these indexes are often not representative. We find it more appropriate to use the classic synoptic classifications, based on a detailed description of synoptic processes of the study area. In Russia, one of the most popular is Dzerdzeevsky's classification (Dzerdzeevsky, 1975; Kononova, 2012). It uses the concept of "elementary circulation mechanisms", and all synoptic processes combine the four basic types: one-zonal circulation, two-zonal and meridional circulation, three-meridional north, four-meridional south. All synoptic processes can be attributed to one of these groups. We use this approach in this study for the detection of the synoptic processes causing strong flooding. We therefore consider these synoptic circulation patterns to cause floods on the Black Sea coast.

Mediterranean cyclones generated at the polar front advect abundant rainfall. The greatest recurrence and intensity of these processes is observed from October until March. However, in summer months these processes are also not infrequent. Cyclones bring intensive precipitation to the Black Sea coast with a high moisture content of wet tropical air, formed over the Mediterranean Sea. During wintertime, these cyclones advect not only abundant precipitation in the form of rain and snow, but also a heatwave, causing intensive snowmelt and thus formation of floods of mixed-type origin. This happened for example on 13 March 2013 in the south of Sochi. In the summer, cyclogenesis over the Mediterranean Sea becomes more active in conditions of large-scale northeasterly flow in the lower and central troposphere. Colder air moves over warm seawater areas and interacts with tropical air masses formed over North Africa. These conditions are very favourable for the formation of an explosive cyclogenesis over the Mediterranean Sea. Similar schemes of circulation are realized in various conditions of the large-scale atmospheric circulation.

Firstly, there are abnormal northern locations of the Azores anticyclone. In recent years, the Azores anticyclone location has moved $1000-1500 \mathrm{~km}$ to the north of its normal climatic position. In such a situation over the Mediterranean Sea, from the Iberian Peninsula to the Balkans, strong cyclogenesis (Fig. 2) becomes active. Small in size, but active, cyclones move from the west to the east. Some enter the terrain of Turkey, but some move through the Black Sea to the Krasnodar and Stavropol territories, the Rostov region and the mid-Volga region.

Secondly, owing to the formation of a warm blocking anticyclone over Eastern Europe (over the water area of the Mediterranean Sea), northeasterly winds are formed. A distinctive feature of this synoptic process is stopping the Mediterranean cyclone over the Black Sea, because the inactive area of high atmospheric pressure blocks the cyclone path to the north or the northeast. Catastrophic inundations were caused by such a cyclone on 6-7 July 2012 in Gelendzhik, Novorossiysk and the Krymsk district of the Krasnodar territory (Fig. 2).

Thirdly, the polar front zone activation, with its axis at about $40^{\circ} \mathrm{N}$ latitude, leads to intensification of cyclogenesis over the Mediterranean. It is often observed in the autumn, when the active frontogenesis combined with high sea 


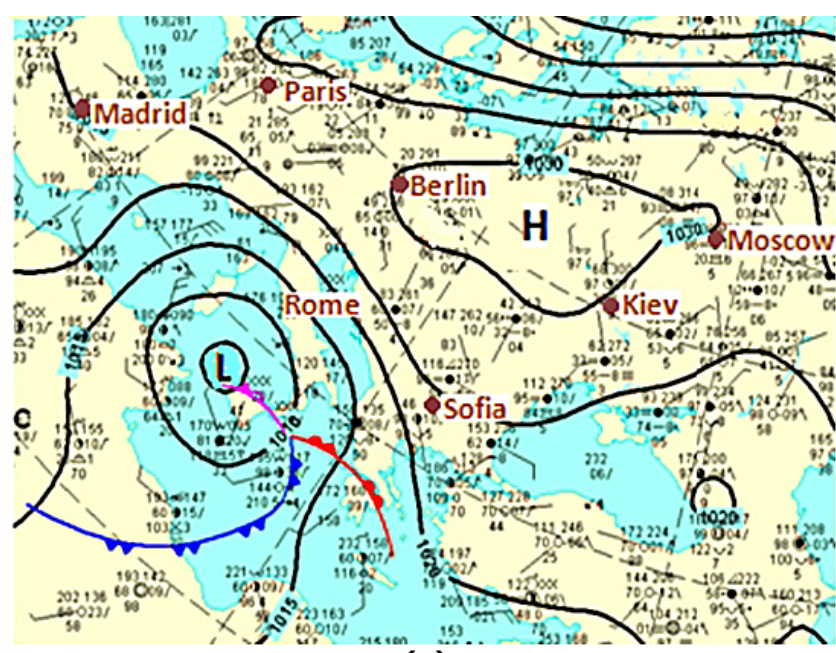

(a)

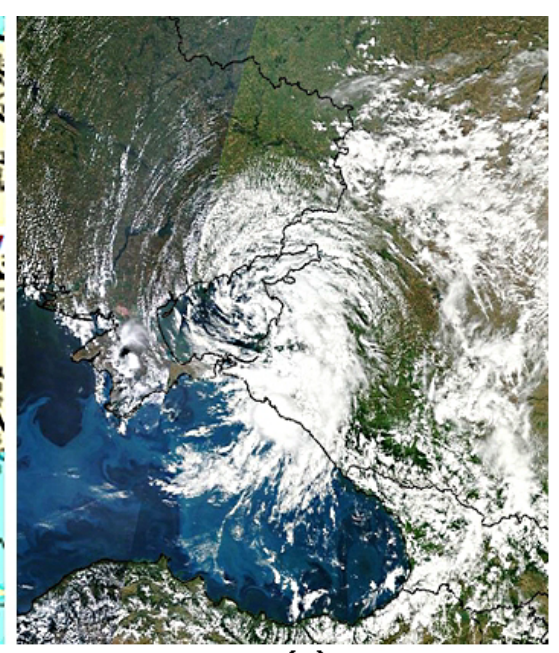

(a)

Figure 2. Different examples of synoptic processes: (a) typical Mediterranean cyclone (marked with the L symbol) and an Atlantic anticyclone (marked with the $\mathrm{H}$ symbol) on a bottom pressure analysis map; (b) the mesocyclone which caused catastrophic inundations in Krymsk in July 2012 (NOAA/Goddard Space Center - NASA EOSDIS LANCE-MODIS: http://lance-modis.eosdis.nasa.gov/imagery/).

surface temperature. During the transit of cold atmospheric fronts of extensive Atlantic cyclones settling down over Eastern Europe or from accompanying quickly displaced deepening cyclones from the northwest, from Scandinavia, abundant precipitation falls. Forced convection in a frontal region in combination with an orographic rise of warm and humid air forms powerful cumulonimbus rain clouds and, hence, strong downpours, thunderstorms and tornadoes. Such conditions led to inundations on 22 August 2012 in the Tuapse district.

In all above events, formation of so-called polar mesocyclones over the Black Sea waters was apparent - the axisymmetric vortex resembling tropical hurricanes. Since the first time this phenomenon was noticed in high latitudes, it has been called a "polar low" (Markowsky and Richardson, 2002; Rasmussen and Turner, 2003). However, these cyclones are also often generated over the Mediterranean and the Black Sea. A polar low is a small, but fairly intense maritime cyclone that forms poleward of the main baroclinic zone (the polar front or other major baroclinic zone) (Rasmussen and Turner, 2003). The horizontal scale of the polar low is approximately between 100 and $1000 \mathrm{~km}$. At least a dozen different length-scale limits for the mesoscale have been defined since Ligda's article. According to this paper (Ligda, 1951), the first radar-detected precipitation area was a thunderstorm observed using a $10 \mathrm{~cm}$ radar in England on 20 February 1941. Organized atmospheric science research using radars was delayed until after World War II due to the importance of the relatively new technology to military interests and the secrecy surrounding radar development. The most popular definitions are those proposed by Orlanski (1975) and Fujita (1981). Orlanski defined the mesoscale as ranging from 2 to $2000 \mathrm{~km}$, with subclassifications of meso- $\alpha$, meso- $\beta$ and meso- $\gamma$ scales referring to horizontal scales of 200-2000, 20-200 and 2-20 km, respectively. Fujita (1981) proposed a much narrower range of length scales in his definition of the mesoscale, where the mesoscale ranged from 4 to $400 \mathrm{~km}$, with sub-classifications of meso- $\alpha$ and meso- $\beta$ scales referring to horizontal scales of $40-400$ and $4-40 \mathrm{~km}$, respectively. According to these two classifications, a polar low is a phenomenon of subsynoptic scale (the horizontalscale synoptic processes of more than $1000 \mathrm{~km}$, and the same mesoscale processes of less than $100 \mathrm{~km}$ ) (Markowsky and Richardson, 2002). The above definition can be extended, if necessary, by specifying the dominant physical mechanism responsible for the development of the low, such as, for example a "baroclinic polar low" or a "convective polar low", the latter being driven primarily by organized convection (Rasmussen and Turner, 2003). A striking example is the weather condition prior to the flooding in Krymsk and Gelendzhik on 6 July 2012. The daily sum of precipitation was $150 \mathrm{~mm}$ in Krymsk (27\% of the annual norm), and $255 \mathrm{~mm}$ in Gelendzhik (36\% annual norm) (Arkhipkin et al., 2013).

In these synoptic situations, the probability of the formation of waterspouts is high. According to the meteorological station data of Tuapse during 1946-1988, 46 cases of formation of waterspouts were recorded. From 2002 until 2011, the Federal Hydrometeorology and Environmental Monitoring Service recorded the formation of about 38 spouts (Baselyuk, 2012). Waterspouts happen mainly in June-September over well-heated coastal regions, in warm and wet unstably stratified air, especially during the advection of cold and rather dry air by a cold atmospheric front. Spouts "descend" from cumulonimbus clouds. The lifetime of a waterspout is from several minutes to several tens of minutes, and they can pass a significant distance. In height, these spouts can 


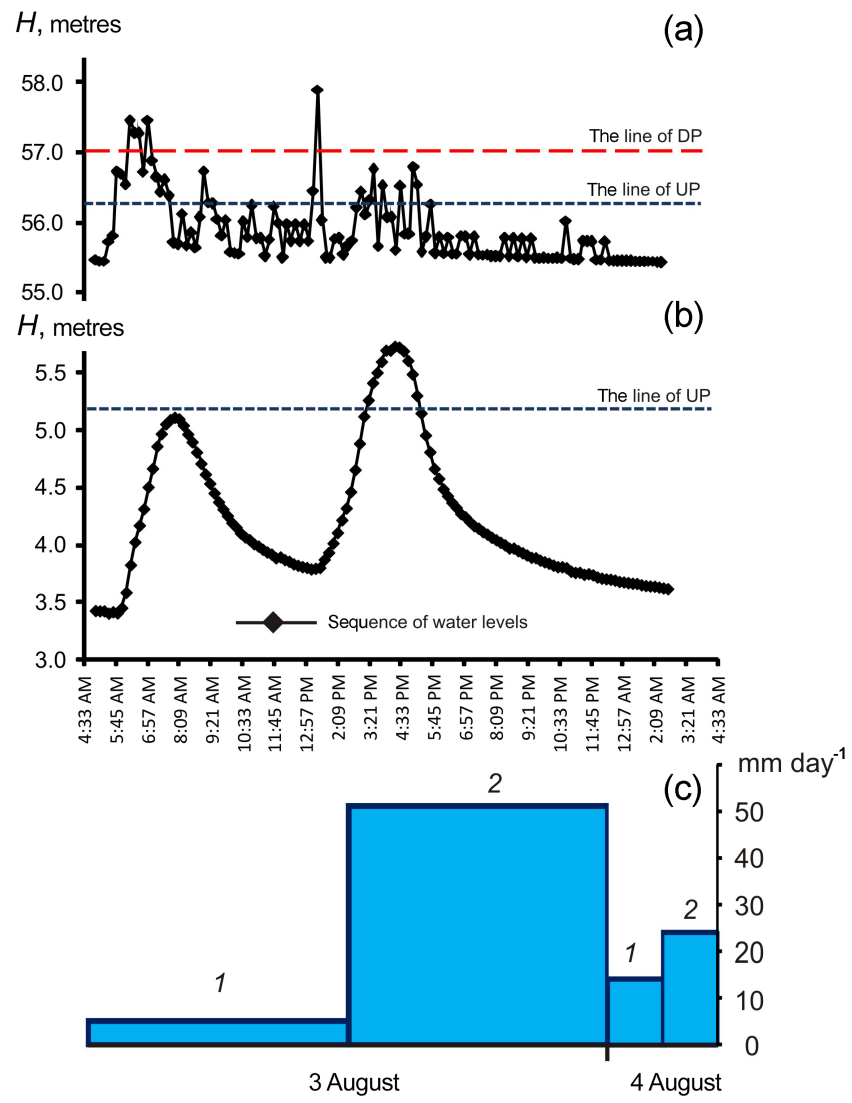

Figure 3. The fluctuations of water level of the Vulan River: at the gauging station of Tekos at $13 \mathrm{~km}$ upstream of the river mouth (a), at gauging station Arkhipo-Osipovka in a river mouth (b) and the diagram of the amount of daily rainfall from 3 to 4 August 2013 (c). Symbols: (1) - rainfall at meteorological station Gelendzhik, (2) - rainfall at meteorological station Dzhubga. Levels are relative to gauge-datum. The velocity of the flood was $2.4 \mathrm{~m} \mathrm{~s}^{-1}$ (at a longitudinal gradient on the reach of 0.004). UP and DP - height of water levels, the excess of which leads to unfavourable (UP) and dangerous (DP) consequences for the population and the economic activities.

reach several hundred metres, with diameters of order of tens of metres. There are eyewitness reports that waterspouts at Novorossiysk on 8 August 2002 had a diameter of $200 \mathrm{~m}$ and a height over $1 \mathrm{~km}$. The spouts formed in the coastal region sometimes cause landfall and move over mountain ridges. As a result, the seawater involved in the circulation of a spout falls into river basins. It is impossible to resolve this process with standard observations; therefore, some experts are sceptical about a "fatal" role of waterspouts in the formation of powerful inundations (Sergin et al., 2001). Nevertheless, evidence of local residents and special research of the Krasnodar branch of Federal Hydrometeorology and Environmental Monitoring Service do not exclude such a possibility. For example, according to data collected during field research after the 8 August 2002 event, the settlement of
Abrau-Dyurso suffered a catastrophic inundation when local residents found fish from the sea in their courtyards, and the river water had a saltish taste. The second example - strong downpours on 20 June 1988 ( $179 \mathrm{~mm}$ for $4 \mathrm{~h}$ and $50 \mathrm{~min}$ ) around Novorossiysk - was observed after the formation of a powerful waterspout over an open part of the sea and its arrival on the east coast of the Tsemessky Bay (Volosuhin and Tkachenko, 2013). Most of the precipitation may be associated with the destruction of the tornado over the coast. Perhaps, it did not even rain; seawater (drawn into the twister) flowed down as a result of the destruction of the tornado. On the western coast of the bay, there was no rain during this day. This fact confirms a local phenomenon (which is characteristic of a tornado).

For the formation of high and dangerous floods, besides the amount of precipitation and their intensity (in the first few hours), the amount of precipitation for previous days and the degree of humidifying of the watershed is important. At strong downpours of $50-100 \mathrm{~mm}$ (and more) in $1-2 \mathrm{~h}$, the intensity of raising the water level in the rivers increases.

\section{Features and regularities of flood routing}

Formation of high and dangerous floods is probable in the upper and middle reaches of the rivers on the Black Sea coast. In a case of heavy rains in the lower river reaches and in a river mouth, flooding depends not so much on raising the water level in the river, but on powerful overland streams from the slopes of the valley. Quite often at the lower reaches of a channel, flood formation starts earlier because the atmospheric water flux moves uphill from the sea, i.e. from the river mouth. For small rivers, a flood can be observed almost momentarily along the entire length of the channel. For large rivers, such a hydrological situation leads to the formation of especially high and destructive floods.

Flood waves in the mountains and foothills move with great speed. It varies depending on the slope of the channels and the amount of water discharges. From the source to the mouth of the rivers, $Q_{\max }$ increases; this supports a high speed of flood propagation, despite a reduction of the slope of the channels. The maximum flow velocities $\left(V_{\max }\right)$ during average height floods range from $1.5-2 \mathrm{~m} \mathrm{~s}^{-1}$ (Gostargayka and Dyurso rivers) to $3.5-4.5 \mathrm{~m} \mathrm{~s}^{-1}$ (the rivers to the south from city of Gelendzhik). The highest flow velocities vary from 5.5 to $7 \mathrm{~m} \mathrm{~s}^{-1}$, but can be even higher. On 7 October 1970 a maximum velocity was measured on the Kuapse river of $V_{\max }=8.75 \mathrm{~m} \mathrm{~s}^{-1}$. Average flow velocities are almost 1.5 times less than the observed maximum. The velocity of propagation of flood waves is also lower (Fig. 3), but because of the lack of reliable data, this is difficult to ascertain.

High floods at the Black Sea Coast rivers - due to the storm character of rainfall, large gradients of surface and rather small dimensions of the basins - are characterized by short duration and an extremely fast rise and subsequent fall of the 


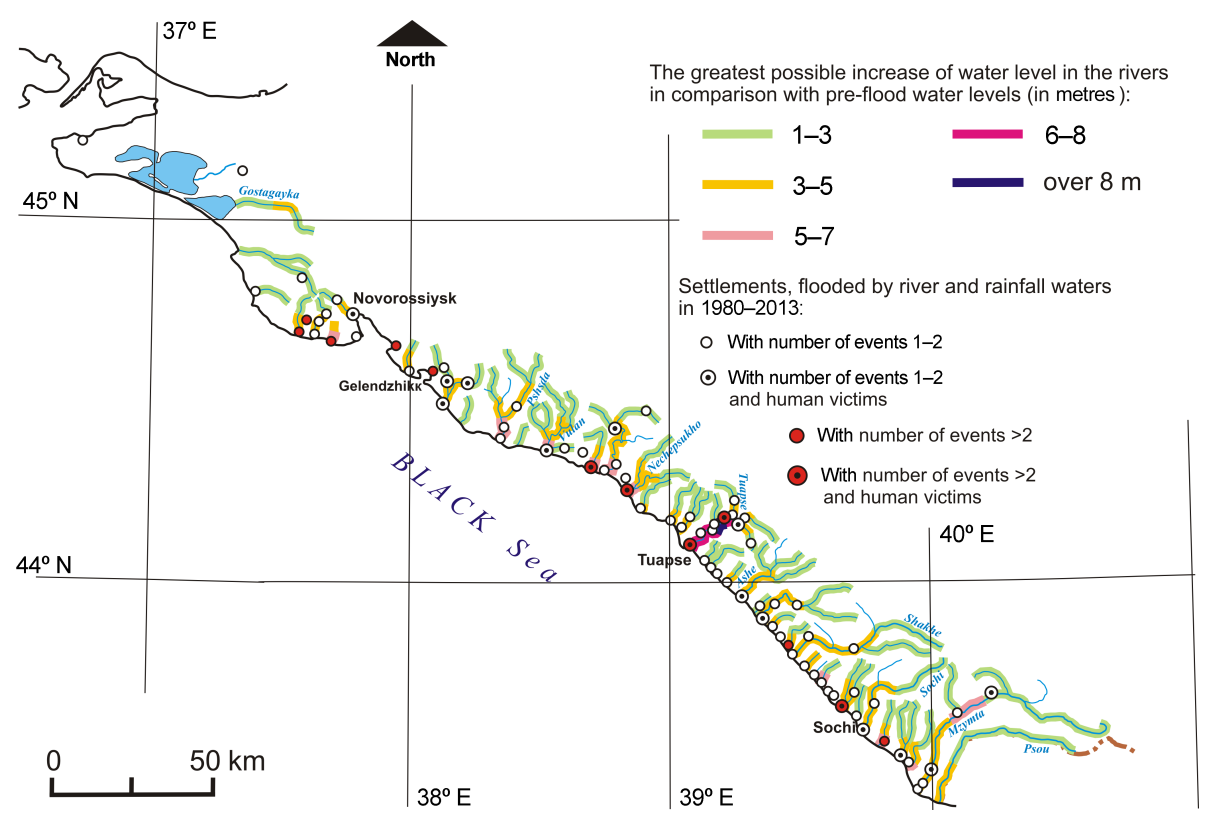

Figure 4. The Black Sea coast of the Russian Federation: difference in value of the greatest possible increase of water levels in river channels, and after-effects of inundations.

water level (Fig. 3). Floods, or their series, can last a number of days. However, the main part of the flood wave passes, as a rule, within several hours - routinely no longer than $0.5-1$ days. However, the part of a flood that leads to flooding is even shorter. For example, the catastrophic flood on the Tuapse River in 1991 lasted $\sim 4.5$ days, its basic part, though, passed approximately within 1 day, and flooding of the floodplain lasted less than $4.5 \mathrm{~h}$ (Panov et al., 2012). Residual flooding of floodplains remains longer.

The maximum rise of level $\left(\Delta H_{\max }\right)$ in the valleys of the Black Sea coast rivers can reach 5-7 m and even higher values (Fig. 4). The extreme water level rise is possible for catastrophic floods at parts of narrowing river valleys and channels, or upstream of bridges. The afflux component of rising water levels upstream of bridges and dams of wooden debris can be $0.5-2 \mathrm{~m}$, but possibly exceeds this value. For example, during the catastrophic flood on 1 August 1991 between the settlements of Kirpichny and Tsypka at a reach of the narrowing valley of the Tuapse River, the water level rise over pre-flood water level amounted to $10-11 \mathrm{~m}$, and upstream of the road bridge in the city of Tuapse was approximately $10 \mathrm{~m}$. At the hydrological gauging station of Tuapse a level of $\Delta H_{\max }=6.72 \mathrm{~m}$ was observed. However, on the coastal rivers there are dominating parts where the rise of water level did not exceed a range of 1 to $3 \mathrm{~m}$.

During abnormally high floods, practically the entire bottom of a river valley is inundated: the width of a stream very quickly increases in time, even by 15-20 times. For example, in 2012, during a flash flood, the width of the Nechepsukho River in the settlement of Novomikhailovskiy, normally with a low flow channel of $20-50 \mathrm{~m}$, increased at the time of the flood to 300-700 m (Fig. 5).

The flood wave undergoes its basic and final transformation at the lowermost reach of the river and in the river mouth, i.e. downstream of the confluence of the last large tributaries. The conditions are an essential widening of the river valley, a reduction of the water slope and a backwater effect from the sea (or from pebble and sand bars blocking the river mouth). As a result, the most dangerous flooding happens (Figs. 5-6) where human settlements are usually found, with resort facilities and other infrastructure objects. The maximum depths of flooding by river waters reach more than $3 \mathrm{~m}$, and by overland streams up to $0.5 \mathrm{~m}$. After the inundation culmination, the largest part of water quickly flows down from floodplains into the river or directly into the sea.

The frequency of flooding of floodplains by river waters is controlled by the elevation of the area and protective dams, and the value and the probability of critical water levels and discharges. Vertical bed deformations, artificial deepening of the channels and the embankment and transformation of natural riverbeds in canals greatly influence the critical value of $Q_{\max }$. Therefore, over time the values of $Q_{\max }$ change. In 1970, near the village of Gostagaevskaya, the water outflow into the floodplain already occurred (in the absence of ice jams) at $Q_{\max }$ with a probability of $10 \%$, whereas now the probability (due to natural and artificial bottom improvement) is $Q_{\max }<3 \%$. In the early 1950 s, the floodplain near the village of Tatyanovka (at the Psezuapse river) could be flooded at $Q_{\max }$ with a probability $<80 \%$; in the early 1990 s the probability was $Q_{\max }<22 \%$. There are numerous such examples. This feature greatly complicates the development 


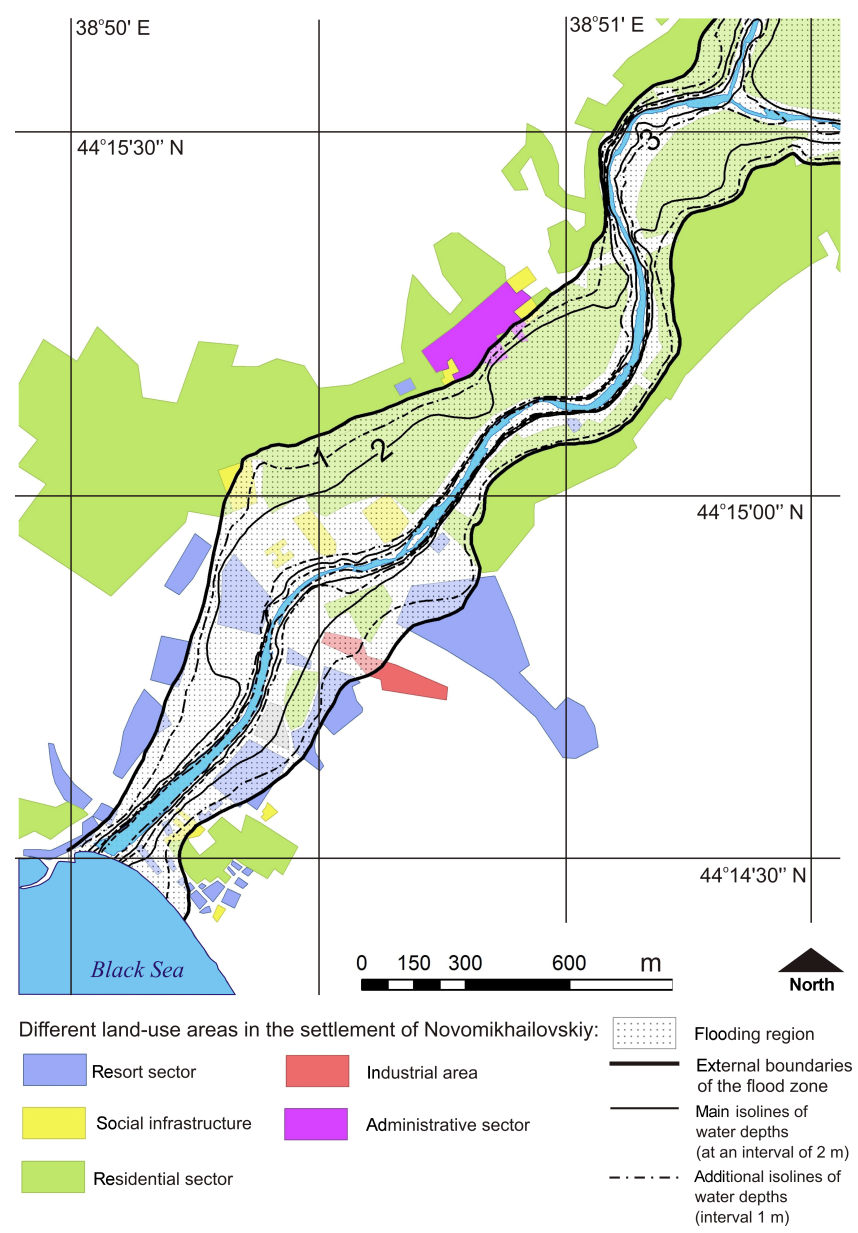

Figure 5. Reconstruction of flooding zone borders and water depths during the river-flow inundations in the settlement of Novomikhailovskiy in 2010 and 2012 (Magritsky et al., 2013).

of effective methods of forecasting dangerous floods and resulting inundations.

In general, horizontal and vertical changes of river channels can reach significant values and create a definite threat for objects in the channel and on the banks. Thus, the flood, similar to the mudflow, on the Matsesta River in September 1913, led to erosion of the riverbanks and shifted the shoreline by more than $400 \mathrm{~m}$. During and after the inundation on the Tuapse River in August 1945, vertical channel erosion at the site of the gauging station and further downstream reached $2 \mathrm{~m}$. The channel of the Ashamba River after a catastrophic high water on 6-7 July 2012 deepened by $2-2.5 \mathrm{~m}$, and at the edge of the floodplain it became wider by 8 to $10 \mathrm{~m}$ (up to $15 \mathrm{~m}$ in places) (Evsyukov et al., 2013). Movement of catastrophic floodwater on the river Shirokaya Balka led to an outwash of channel depositions $10 \mathrm{~m}$ deep, reaching the bedrock, on 9 August 2002 (Barinov, 2009). There are again many examples of this kind.

During floods, together with the water, great volumes of deposits and debris are moved downstream. Quite often

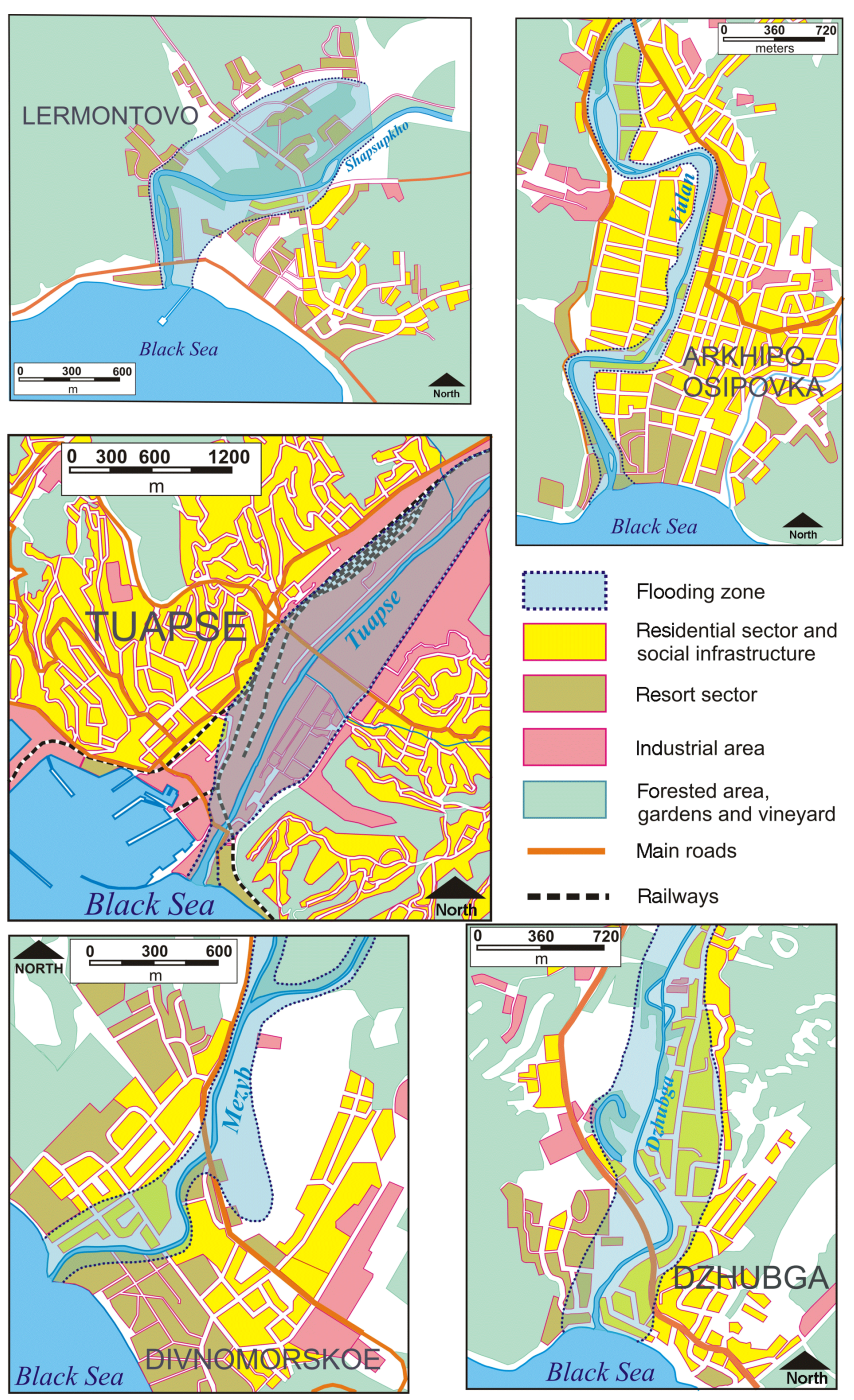

Figure 6. Borders of flooding zones in the mouths of the rivers Shapsukho (settlement of Lermontovo; area of flooding $F \approx 0.83 \mathrm{~km}^{2}$ ), Vulan (settlement of Arkhipo-Osipovka; $F \approx 0.73 \mathrm{~km}^{2}$ ), Tuapse (Tuapse; $F \approx 2.1 \mathrm{~km}^{2}$ ), Mezyb (settlement of Divnomorskiy; $F \approx 0.44 \mathrm{~km}^{2}$ ) and Dzhubga (settlement of Dzhubga; $F \approx 0.8 \mathrm{~km}^{2}$ ) during the big and catastrophic inundations.

floods transform into mudflows, possessing even greater destructive ability, which leads to greater hydromorphological changes, economic losses and negative ecological effects. The main part of deposits accumulates, firstly, on the floodplain in the lower reaches and at the mouths of the Black Sea coastal rivers. Therefore, besides destruction, the river water unloads a thick layer (10-20 cm and more) of deposits, of debris and of refuse (Fig. 7a) on the floodplain. This is another aspect of the adverse effects of inundations together with channel deformations, deterioration of water quality in rivers and the near-shore zone of the sea. Deposits from floods and 


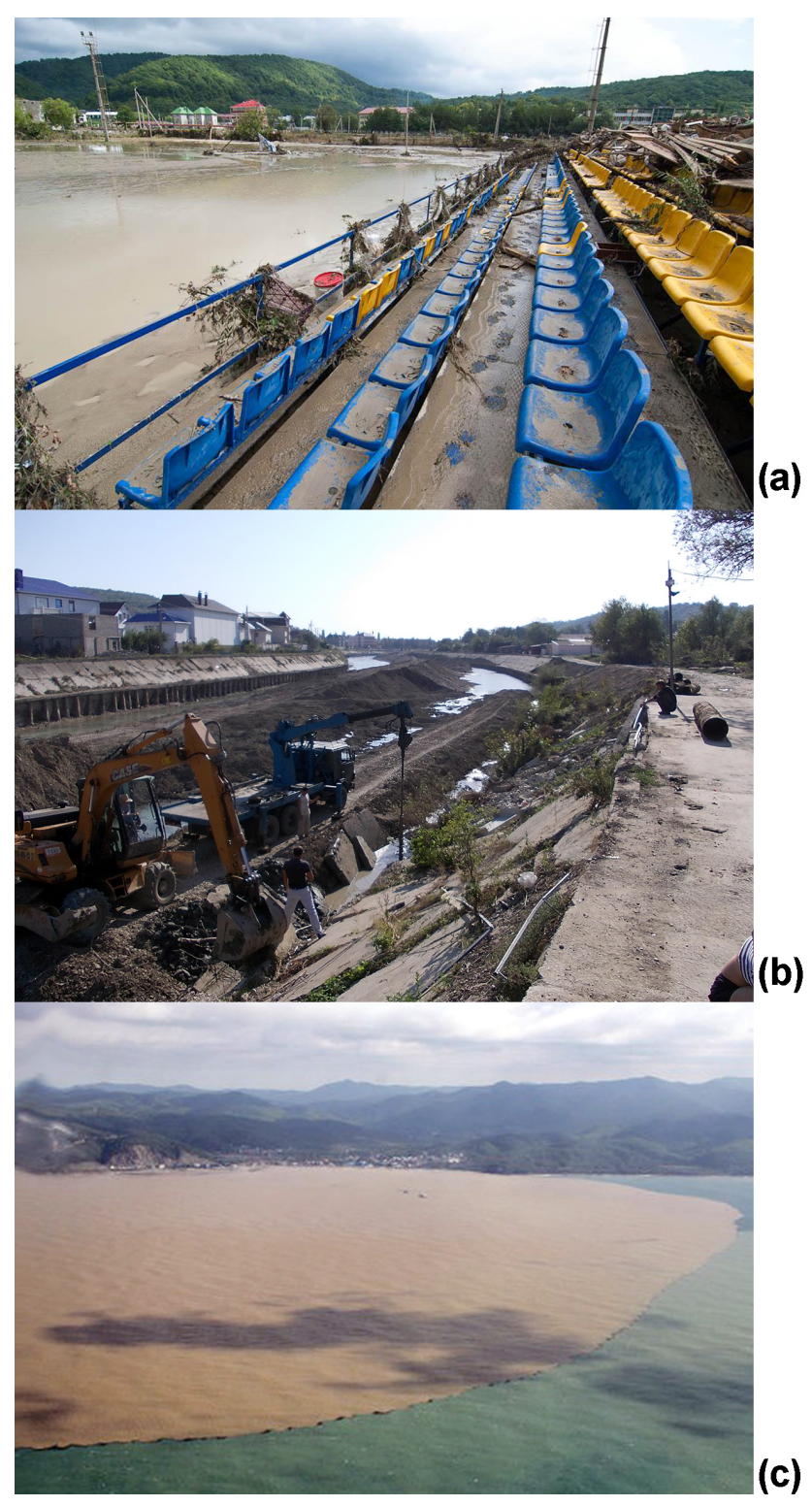

Figure 7. Consequences of a catastrophic flood high water in August 2012. Settlement Novomikhailovskiy (Tuapse district). (a) Depositions of river sediments and refuse in the city stadium (August 2012; www.livekuban.ru); (b) clearing the channel from deposits and vegetation (October, 2012, D. V. Magritsky); (c) turbid plume in the mouth of the Nechepsukho river (August, 2012; http://ria.ru/).

particularly mudflows seriously increase flood damage on developed terrain and of civil constructions.

Secondly, a significant part of deposits are accumulated in channels that lead to a reduction of their water transport capacity. If a channel is not periodically dredged, its transport capacity quickly diminishes. As a result, the frequency of dangerous flooding increases. It also happened in the settlement of Novomikhailovskiy in 2010 and 2012, despite considerable protection measures against the inundations in the settlement in the twentieth century, including high and continuous dams, and a wide and improved channel. Only after the last inundation, has the channel cleaning started (Fig. 7b).

Thirdly, parts of the deposits remain in river mouths where these depositions quite often form a bar shoal which is later washed away during strong autumn-winter-spring storms. Other parts (very fine-sediment particle fractions) are carried away into the sea, forming a strongly pronounced turbid plume, unfavourable for recreational activities of resorts and deteriorating habitat conditions of aquatic organisms (Fig. 7c).

\section{Temporal regularities of inundations}

Despite a characteristic distribution of floods and of water flow within a year (Table 1, Fig. 1), almost $71 \%$ of all catastrophic and exceptional inundations took place in July-August $(71 \%)$ and in October-November (29\%). Some $52 \%$ of large inundations happen in the summer and $26 \%$ in the September-October period. The principal reason of such distribution is the increase of extreme rainfall in the warm season. According to meteorological records, nine rain events with a total precipitation $>100 \mathrm{~mm} \mathrm{~d}^{-1}$ happened in the last 50 years in November-February while in MayOctober such downpours were observed at least 46 times, and in $85 \%$ of cases in June-September. In March-April, there are no records of such rainfall. Besides, heavy rains in the cold season have a longer time duration than in the warm period. This reduces the probability of the formation of dangerous high waters. The contribution from water tornadoes formed in the coastal region from June until October can be one more factor for increasing flood levels.

Conversely, the seasonal distribution of small and moderately dangerous inundations reflects, on average, a water regime of two groups of rivers of the coast - to the north of the Tuapse River, and to the south. It is characterized by sufficient uniformity. Some $30 \%$ of such inundations take place in winter, in the spring $12 \%$, in the summer $28 \%$ and in autumn $30 \%$. The safest months with respect to inundations of all types are March (3.5\%) and especially April (1.5\%).

At longer timescales, we can observe a non-linear and statistically insignificant trend of the increase of the number of inundations and, hence, of the expected damage (Fig. 8). It is caused by a noticeable increase of the number of inundations, mainly in the period from the beginning of 1970s until the early years of the twenty-first century. This positive trend can be challenged, but the objective reasons for it, nevertheless, exist. Firstly, these are the climatic changes observed in the region (Kononova, 2012; Panov et al., 2012; Sergin et al., 2001; Volosuhin and Tkachenko, 2013). The increase in water flow at a number of rivers (absolutely unequally distributed at the different rivers in this small territory), and mainly peak water discharges (especially in last quarter of the twentieth century) and maximum flow extremes (Fig. 9) are 
considered as the hydrological reaction to these processes. This is true particularly, for example, for the increase of anomalously high peak discharges of water, such as in 1980, 1991, 1997, 2002, 2010 and 2012 and the statistically significant (at $\alpha=5 \%$ ) violation of homogeneity of time series of the peak discharges (at the some rivers) in respect of the dispersion.

The climatic origin of the long-term dynamics of the number of inundations is obviously a combination of the number of inundations and the total (for a year) duration of southern longitude-type circulations of the Northern Hemisphere (in B.L. Dzerdzeevsky's typification), characterized by the intensifying role of southern cyclones. According to Kononova (2012), from the end of the 1950s onwards, the increase of the duration of this type of circulation (Fig. 8b) is noted. In the early sixties, for the first time in 112 years of record (from 1899 until 2012) southern longitude processes exceeded their average number. An unprecedented growth of the duration of southern longitude processes began in the 1980s and only after 2000 started to drop, but they are still above the average level. The same dynamics can be found in the annual total numbers of precipitation in the region of the Krasnodar territory (Volosuhin and Tkachenko, 2013). Simultaneously, with weakening of the southern longitude processes in the 2000s, a significant increase in the frequency of northern longitude processes is noted.

Secondly, the growth of the number of extreme inundations can be a consequence of a wide scale and not always prudent economic activity. It often includes intensive construction works at floodplains and on alluvial cones of river mouths (Fig. 10), where 100 years ago there still was no activity, and in the late eighties, with the beginning of the 1990s where in most cases only temporary constructions and kitchen gardens were established. The other reasons could be the termination (or decrease in scales) of works in the PostSoviet period of dredging channels and maintaining protective dams in good condition (Fig. 7), and unreasonable and intensive land use on watersheds. A number of scientists connect the increase in the twentieth century (in comparison with the nineteenth century) of inundations, mudflows, rockfalls and landslides to the last factor. In general, the anthropogenic contribution to inundations for the Black Sea coast is considerable; its effect constantly grows, breaking the relations between characteristics of inundations both of natural climatic and hydrological factors, and enhancing differences in their interannual variability, and finally increasing the magnitude of inundations. The last example is an inundation on 7 July 2012 in Krymsk. According to the prevailing weather conditions, it would have been considerable, but has outgrown any expectations due to a combination of several anthropogenic factors. They are as follows: (1) the accumulation of the large volume of water in fish-breeding ponds and the headwater upstream of the bridge, and its subsequent outbreak, (2) the destruction of trees in the river basin, (3) the location of res- idential buildings in an area of potential flooding, (4) the untimely informing of the population.

Without a thorough discussion of this point, it will be impossible to quantify and respond to hydrological hazards, and to predict changes of inundations in the future. Recent work supports the tendency we observe for the future (Matveeva et al., 2013). The data of the climate model ECHAM5/MPI-OM (scenario A2) have highlighted that during the summer season of 2046-2065, an intensive frontal zone (one of the synoptic predictors of abundant precipitation) will occur double as often than in 1981-2000, and 3 times more than in 1961-1980. For the winter season a reverse relationship is observed: in the conditions of climate warming, the number of cases with an intensive frontal zone will be lower by 1.75 times and 1.4 times in comparison with 1981-2000 and 1961-1980 periods accordingly (Matveeva et al., 2013).

Another feature of the interannual dynamics of the number of inundations at the Black Sea coast of the Russian Federation is their recurrence with a duration of cycles from 6-7 to 10-12 years (Fig. 9). The spectral analysis of the time series with the program STATISTICA 10 (for five basic transformations and at different window width of the sliding average) has revealed the highest peak of the periodogram and spectral density for the period of $\sim 8$ years' duration and essentially smaller in height at 7 years. Smaller peaks are found for the periods of 3.5, 5.0 and 23 and at 11-12 years. A similar recurrence was found in the number of inundations in the whole North Caucasus during 1980-2013 (Magritsky et al., 2013b) and by Volosuhin and Tkachenko (2013) in the change of the quantity of floods of category DP on the rivers of the Krasnodar territory. Therefore, a temporary reduction of the number and magnitude of inundations does not mean that in the near future (during a specified period) there will be no new complications of the situation with inundations. The tragic events of 2002, 2010 and 2012 show what can happen in cases of self-complacency.

\section{Geographical features and hazard of inundations}

Orographic features of the coast and features of rainfall, river-flow inundations and inundations of the mixed type no. 1 as a rule cover only a small number of local river basins and a limited area, especially in the case of rain showers of tornado origin. Therefore, the spatial correlation of $Q_{\max }$ for the coastal rivers is rather insignificant and quickly decreases with distance between watersheds. Within the first $50 \mathrm{~km}$, the correlation coefficient $(r)$ still can reach significant values more than $0.6-0.7$ (at a wide range of fluctuations - from 0 to 0.9 ). Within $50-75 \mathrm{~km}, r$ drops to $0.5-0.6$ and less, within $75-125 \mathrm{~km}, r \leq 0.5-0.4$ and for distances of $125-150 \mathrm{~km}$ and more, $r$ decreases to $0.2-0.1$ and less. On average, the correlation for $Q_{\max }$ ceases to be statistically significant (at the level of significance $\alpha=5 \%$ and the available duration of records) for the distances over $40-60 \mathrm{~km}$. The time of the 


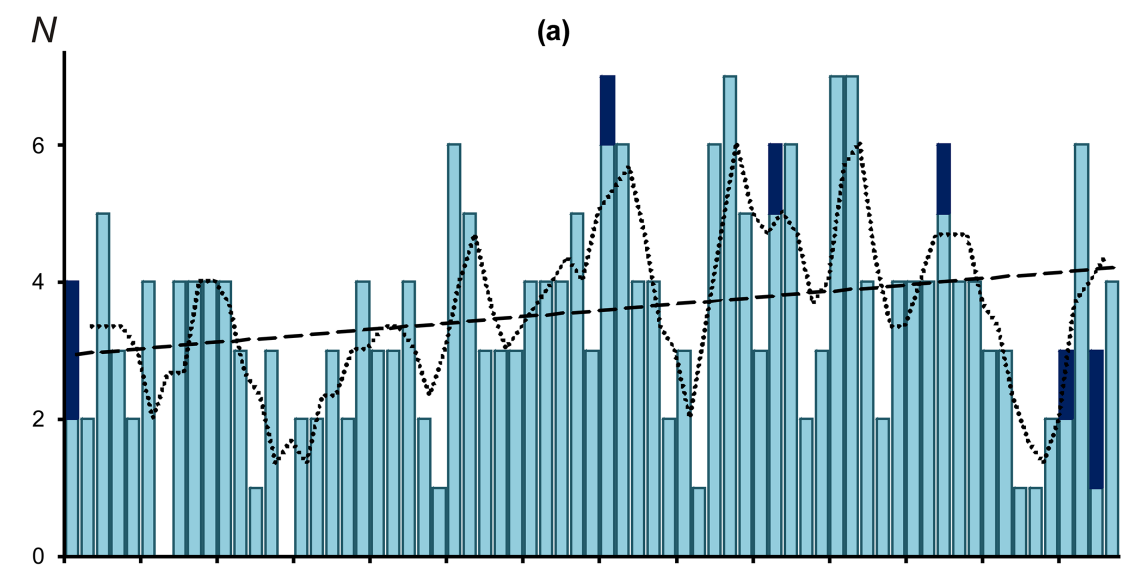

Days

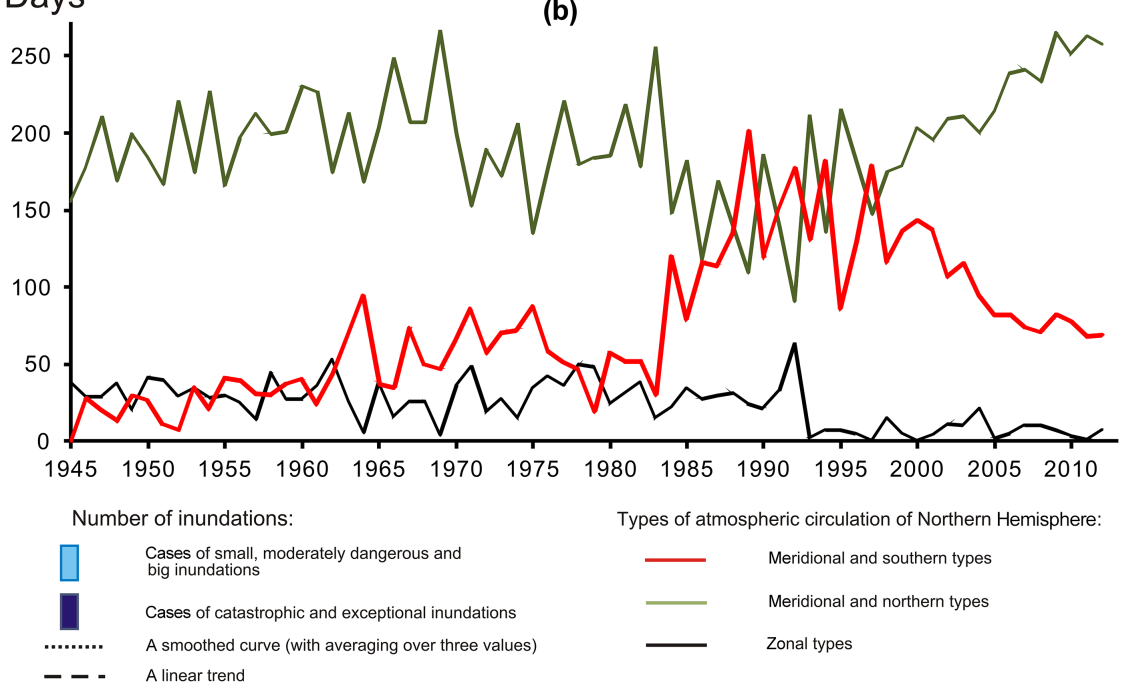

Figure 8. Interannual changes of the number of inundations at the Black Sea coast of the Krasnodar territory (a) and fluctuation of total duration for a year of groups of types of atmospheric circulation of the Northern Hemisphere in B. L. Dzerdzeevsky's typification in 19452013 (b; by data from site: http://atmospheric-circulation.ru/datas/).
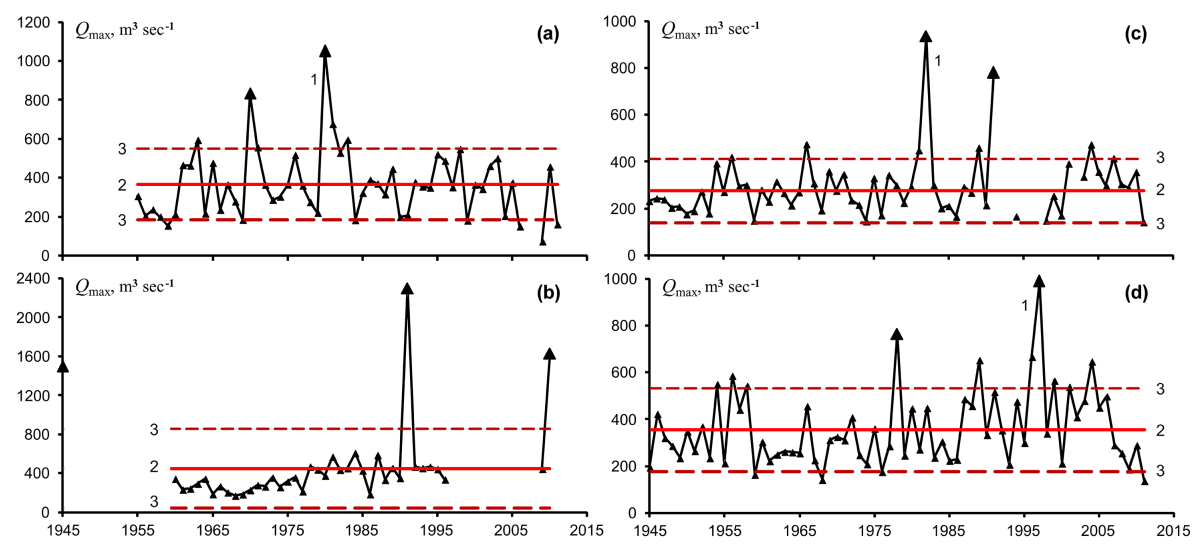

Figure 9. Long-term fluctuations of the maximum water discharges of the rivers Vulan (a), Tuapse (b), Shakhe (c) and Sochi (d): 1 maximum water discharges, 2 - mean annual water discharge, 3 - maximum deviation from the mean annual water discharge by $1 \sigma$. 


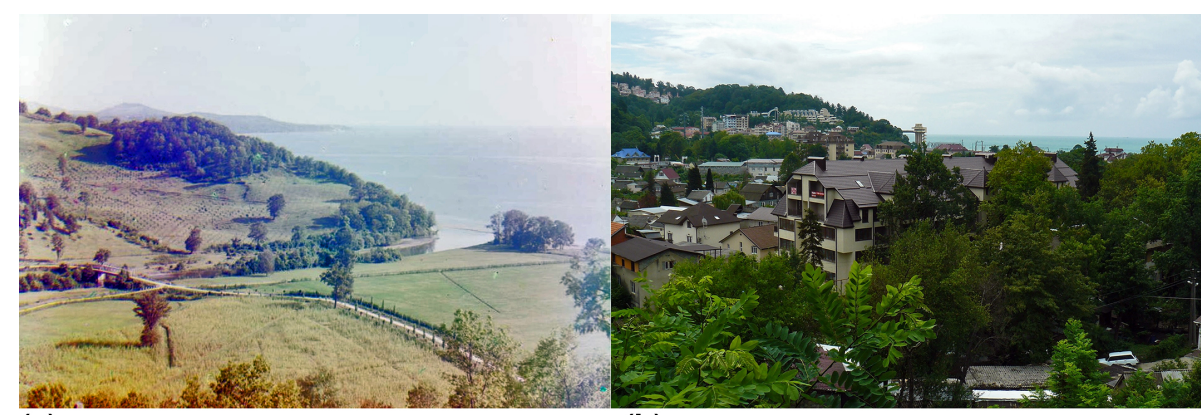

(a)

(b)

Figure 10. Land use change, new buildings and infrastructure: mouth of the Dagomys River (the city resort of Sochi) in the beginning of the twentieth century and in the beginning of the twenty-first century. The image in (a) is Prokudin-Gorskiy's photo (1910-1915, Library of the Congress of the USA). The image in (b) is a photo from an online resource; http://www.panoramio.com, user no. 61728391 (on 18 August 2013).

maximum water discharges for a year on the Black Sea rivers and subsequent inundations sometimes coincides with $Q_{\max }$. Inundations are observed on the rivers of the northern slope of the Caucasus, such as the rivers of Novorossiysk and Gelendzhik - with the rivers on the stretch from the Gechepsin River to the Afips River, on the rivers of the Tuapse district and the northern part of Sochi and on the rivers in the basins of the Psekups, Pshish and Belaya. The last observed event took place in July 2012. Catastrophic inundations can cover even larger extended areas, affecting even the southern extremity of the arid Anapa municipal district as in August 2002.

Inundations at the Black Sea coast of the Krasnodar administrative territory vary irregularly, despite their small spatial dimensions. The least affected are Temryuk (not including the delta of the Kuban River) and the Anapa municipal districts, because the conditions are mostly flat and foothill terrain, a small amount of precipitation and rarely a channel network. Significant damage was recorded here from local storm rainfall floods: in Temryuk district, about six cases are known since 1972, in Anapa about 11 cases since 1960. In the summer of 2003 such an inundation caused destruction in the village of Taman with a damage of RUB 2.5 million (Magritsky et al., 2013a). Because of the low and flat coast between Anapa and the settlement of Veselovka, the shallow sea near the coast and the spoon-like shape of the shore, there is a certain potential danger of storm surges and of tsunami. In addition, numerous artificial water reservoirs (ponds) are potentially dangerous from the point of view of their possible outbreak. In the Anapa district such reservoirs are very numerous: nearly 39 in number and with the total area of $3.5 \mathrm{~km}^{2}$ (Panov et al., 2012). The ponds are formed by dams on the rivers; these constructions are usually old and not robust. During the high flood the dam outbreak can increase the magnitude of the event dramatically. For example, according to our data, such a catastrophic flood took place on the Durso River in the summer of 2002.
In the Novorossiysk, Gelendzhik, Tuapse and Sochi municipal areas, floods caused by extreme rain and powerful slope streams often lead to inundations. River-flow inundations result from snowmelt runoff to a much lesser extent (as in 1981, the rivers of Mezyb and Vulan; 2003 and 2013, the Mzymta river), or by breaking of dammed lakes (in 1968, the Mzymta river) and ponds (in 1977, the Mzymta river) or a combination of several factors. Even more often, mass media report about local flooding of settlements by storm waters and by slope streams. Additionally in this part of the coast, powerful floods are possible during windwave surges. Seaport infrastructure and objects of the resort/recreational economic sector, first of all, suffer from these. Similar events were noted, for example, in 1968 in the mouth of the Dagomys River, in 1992 on the reach between Sochi and Adler and in 2003 and 2009 in the mouth of the Mzymta River.

The average interannual repeatability of river flow and of inundations of the mixed type no. 1 in the Novorossiysk, Gelendzhik, Tuapse areas and in Sochi is approximately once in $2.1,0.9,0.7$ and 0.45 years respectively. For comparison, in Anapa it happens once in 6 years, and for the whole Black Sea coast once in 0.3 year. The percentage of small and moderately dangerous inundations is equal to $87 \%$ in Novorossiysk, Gelendzhik and Tuapse districts. In Sochi, this percentage reaches $92 \%$, in Anapa almost $100 \%$. Other cases are big, catastrophic and exceptional inundations. Most catastrophic and exceptional inundations, in total four, occurred between 1945 and 2013 on the rivers of the Tuapse district.

In Sochi, large hazards of inundations are conditioned by the large area of the terrain, the number and length of the rivers, the higher amount of precipitation and the number of settlements. Most casualties were recorded for the Novorossiysk, Gelendzhik and Tuapse districts. One of the factors of such regularity is the greater level of water level rise, inherent to the rivers of Novorossiysk, Gelendzhik and 


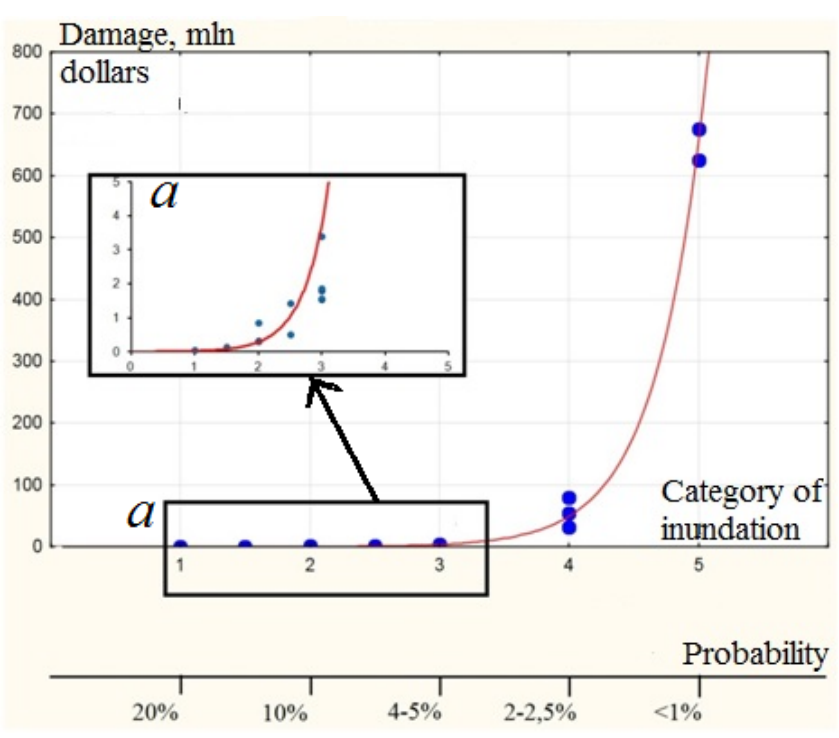

Figure 11. Empirical relationship between direct material damage (millions of US dollars) and type of inundation (river flow and the mixed type no. 1 inundations), or probability of $Q_{\max } \cdot a$ is the lower part of the curve (zoom between categories 1-3).

Tuapse area (Fig.3); another, is the fast formation and transit of floods on the rivers of these areas, because of their small dimensions, and often the mudflow character of the floods.

Most inundations happen in the lower reaches and the mouths of the Black Sea coastal rivers and there is, accordingly, greater damage and higher losses. Large economical activities and larger populations are concentrated there, and most of the factors of "spontaneous behaviour" of river, rainfall and seawater take place. Therefore, a stricter approach is necessary for this terrain with a higher degree of scrutiny with respect to issuing permission for the placement of social and industrial objects in this region (land use and land planning), for the estimation of cost of their insurance and of the protective action and for the population evacuation in case of emergency.

During catastrophic inundations, the resultant damage is huge without depending on the information on dimensions of the terrain and the number of watersheds subjected to storm precipitation and rising water level in the rivers. According to data of the electronic database "Inundations in the river mouths of the European part of Russia" (Alexeevsky et al., 2013), the damage from exceptional inundations in August 1991 was estimated at approximately RUB 400 million (or USD 680 million, according to the official exchange rates of the Central Bank of the Russian Federation for different years), from which RUB 363 million (USD 615 million) was attributed to the terrain of the coast. The number of casualties reached about 40 people, including 11 people who were missing. Inundations in August 2002 led to damage of roughly RUB 1.7 billion (USD 54 million) and casualties $\sim 60$ (including missing people); in October, $2010-$ in
RUB 2.5 billion (USD 80 million) and 24 people dead; in August 2012 - RUB 1 billion (USD 32 million) and four people lost their lives. The exceptional inundation in July 2012 is not included in this list, as the main impact of the natural disaster and the damage was in the Krasnodar territory outside the Black Sea coast. During the big inundations, human casualties also are possible; the size of direct material damage varies from several hundred thousand to several millions dollars, but, according to the available scarce data, has not exceeded 4-5 million dollars for the Black Sea coast rivers.

Between the magnitude of inundation and the value of direct material damage there is an obvious and explainable relationship where the value of the damage increases (when moving from small inundations to more destructive ones) as the curve is close to an exponential function, but with higher steepness (Fig. 11). Certainly, the reliability of the relationship developed by the authors of the paper still is low; the confidence interval is wide. The reasons are the small number of cases (17 values) and the low reliability of the initial data. However, similar relationships essentially dictate our understanding of the danger of those or other inundations.

In general, the annual economic risk of river-flow inundations and inundations of the mixed type no. 1 can be estimated approximately for all the Black Sea coast of the Russian Federation at USD 13.2 million, and the social risk at 2.1 human lives. In the area of possible flooding, the risk varies from 49 (data of the authors) to 74 settlements (open information of the Ministry of Civil Defence and Emergency Situations for the Krasnodar territory), and about 3100 residence houses and 18200 inhabitants.

\section{Countermeasures for inundations and their efficiency}

Economic and social losses from inundations at the Black Sea coast of the Krasnodar territory are one of the highest in the Russian Federation. Therefore, one important direction for safe and sustainable development of this area remains in the implementation of various actions for a reduction of this hazard. The last catastrophic events and the preceding conditions have highlighted weaknesses of traditional measures, consequences of their non-observance and initiated the search for new solutions.

The basic conclusion from recent inundations consists of the need to consider (as objects of the efforts) not only the lower reaches and mouths of the Black Sea coast rivers where the main part of the social and economic development of the coast is concentrated, but also whole river basins and catchments (Magritsky et al., 2013a; Sergin et al., 2001). This is the watershed, where its physiographic features determine the time of concentration of surface runoff water in river channels, the saturation of a river stream by suspended load, debris and other refuse and the transformation of a common flood into a mudflow. Therefore, the countermeasures for inundations should necessarily include well-defined actions on 
river watersheds. These measures should include steps aiming towards the improvement of the water-controlling ability of reservoirs (by means of stopping woodcutting in mountain forests, optimization of composition of forest vegetation, etc.), the reduction of erosion of bedrock and the reduction of littering of slopes of river valleys and riverbanks.

Definitely, basic measures are necessary in the middle and especially in the lower reaches of the rivers. Among engineering measures, for a long time and successfully carried out here, these are the construction of bank dams, deepening and improving river channels, and reinforcement and protection of riverbanks against flood erosion. For example, out of 48 rivers discharging to the sea between Tuapse and the settlement of Leselidze, 20 channels, i.e. $42 \%$, were improved. However, these measures are only effective if the embankments/dams are in good condition and of sufficient height, the river channel is constantly cleaned from depositions and debris, the channel improved and maintaining sufficient transport capacity, not only for water but also for the considerable quantity of deposits, debris and that this capacity remains maintained under the bridges. Default, or infringement of these and other requirements lead to those consequences, which all can observe, for example in the settlement of Novomikhailovskiy during the large inundations in 2010 and 2012.

At the same time, dredging channels and the removal of boulders, pebbles, gravel and sand from a channel and from floodplains should be carried out, taking into account possible adverse consequences of this action. Accompanying this action, there are many that can overturn any positive effect:

- decrease of the low flow water level in rivers,

- lowering of ground water level,

- the almost inevitable water supply infringement,

- undermining and infringement of the stability of hydraulic constructions in the channel and on the banks,

- change of the balance of beach-forming deposits and intensifying of the vulnerability of sea beaches.

Other engineering measures such as the increase in height of dams around the objects of importance, channel replacement, as in a case in the lower reach of the Tuapse River, maintenance of free drainage or filtration of rainwater in inhabited terrains are also suggested. At present, the operative practice of artificial dam-breaking of coastal barriers in the river mouth is rarely applied. Coastal barriers formed by sea waves and storm surges block the river channel and do not allow the river waters to flow freely into the sea. At the approach of the flood wave, the coastal dam, which routinely protects the mouths of the Black Sea rivers from wind-induced sea surges, is at the initial moment of the development of inundations a serious obstacle for the free discharge of river water into the sea; i.e. this is one more factor to contribute to inundation.

Regulating the maximum flow by water reservoirs on the Black Sea rivers is ineffective, owing to the impossibility of building in this region large regulating storage capacity. They fill up fast with sediment, including landslip and mudflow deposits. Additionally there is a high danger of destruction of the dams because of the high seismicity of the terrain. Where artificial reservoirs nevertheless are built, they are an additional factor leading to powerful natural/anthropogenic river-flow inundations. Therefore, such hydraulic engineering structures should be constructed under multi-hazard aspects and designed very reliably.

Among non-engineering approaches, it is necessary to pay attention, first, to an increase of efficacy of the preliminary forecasts of the maximum water levels and discharge, the timely warning of the population and subjects of economy about the approach of the flood. Modernization of the hydrometeorological monitoring system for this purpose is required. The first steps in this direction have already been made by the Ministry of Emergency and Civil Defence in the Krasnodar territory. Since November 2012, the computerized system of monitoring flood situations on the rivers and reservoirs (http://test.emercit.com/overall.html) in the region has been in place. The installation of several rain radar-tracking stations for monitoring the intensity and quantity of precipitation is required. Vulnerability assessment and an increase of preparedness of the local population are also important aspects among measures of flood risk minimization (Zemtsov, 2014).

For the next steps, a clear understanding of the reasons, features and systematics of the origin and development of inundations and their adverse hydrologic-ecological, morphological, social and economic consequences is necessary. Here are good prospects for numerical modelling and GIS technologies (Fig. 12). Modelling of water and debris flow is required to estimate flooding borders, water levels, depths and flow velocities in key areas. Such data could be the base for a detailed hazard assessment and zonation of the river valleys (Petrakov et al., 2012).

Different restrictions (by various means - from administrative measures to flexible flood insurance) are necessary for the process of developing the territory in order to reduce its potential flooding hazard. For this purpose, these limits (for inundations different in their dimensions) should be made known and the terrains differentiated at the degree of their hydrological hazards. This will be required for solid land-use planning and planning permissions.

\section{Conclusions}

The list of the dangerous natural phenomena at the Black Sea coast of the Krasnodar territory of the Russian Federation is extensive, but inundations cause the greatest damage. 


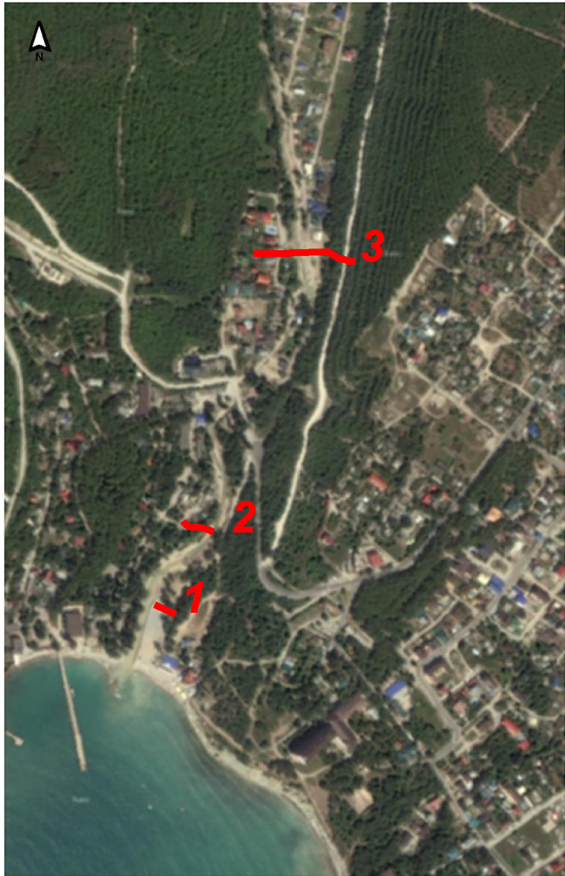

(a)

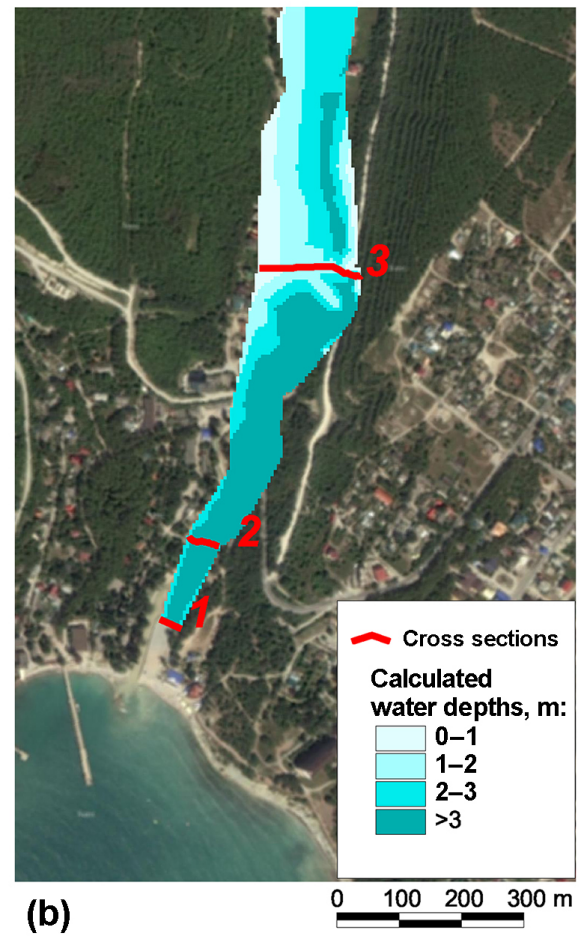

(b)

Figure 12. An example of numerical modelling of inundation in the valley of the Ashamba River (terrain of city resort Gelendzhik): (a) terrain before flood, (b) calculated maximum flood depths.

Such a situation arises from the influence and interactions of many different factors. Among natural factors are the specific location of the area, the complex orography of the territory, the high drainage density, small basins area and the big water slopes and weak regulating ability of river watersheds. An important role is played by the large quantity and the extremeness of rainfall, and the intense flood regimes of the rivers. Extreme floods are formed and move down along the valley rapidly. This leads to a fast substantial increase of water levels, the frequent transformation of rain floods into mudflow-like streams, the contribution of powerful storm and overland streams to additional terrain flooding. Among anthropogenic factors are the location of the main part of settlements, objects of the industry, social sphere and the resort industry, the transport infrastructure in river valleys and the mouths of the Black Sea coastal rivers.

At origin on the Black Sea coast, inundations are generated by river flow and river flow, combined with rainstorms (inundations of the mixed type no. 1). They dominate in number, repeatability and damage values. At the coast and in river mouths the inundation can be caused also by storm surges, or by storm-wave-induced surges, and the interaction of river and the sea. We can distinguish inundations by terrain coverage (the number of involved watersheds and rivers) and intensity, and by magnitude of the damage - small, moderately dangerous, large, catastrophic and exceptional inun- dations. The probability of their occurrence accordingly is $\sim 20, \sim 10, \sim 4-5, \sim 2-2.5$ and $<1 \%$ respectively.

The floods, which lead to river-flow inundations and the mixed type no. 1 inundations, are formed by abundant and heavy storm rainfall. This occurs with the transit of southern cyclones, cold atmospheric fronts of extensive Atlantic cyclones covering Eastern Europe or accompanying cyclones quickly arriving from the northwest. As a special case, extreme rainfall discharges as a result of the destruction of seaborne tornadoes on land. The mountain relief has a considerable role in the formation of abundant precipitation. Catastrophic inundations are generated by an abnormal combination of synoptic processes and convective phenomena.

The characteristic features of dangerous floods are their rapid formation and propagation, a significant increase of water level (up to 5-7 m and more) and multiple increase of water discharges (at times practically from values close to zero to several hundred $\mathrm{m}^{3} \mathrm{~s}^{-1}$ and even $>1000 \mathrm{~m}^{3} \mathrm{~s}^{-1}$ ). During floods, practically the entire bottom of the river valley can be submerged, therefore all this terrain becomes a region of significant risks for land use and management. The flood wave undergoes main and dangerous transformations at the lowermost reach of the channel and in the river mouth where settlements and basic economic objects routinely are developed. The maximum heights of flooding by river waters can reach 2-3 m here, and in slope streams $0.5 \mathrm{~m}$. Flooding lasts some hours routinely; residual floods continue longer. 
Floods carry great volumes of sediments and debris together with the water. Quite often, floods transform into mudflow streams with a high destructive capability, and have, different from floods, severe hydrological-morphological, economic and ecological consequences.

Most catastrophic and exceptional inundations arise in the summer and in the early autumn. Small inundations during the remaining year reflect the seasonal distribution of river flow and floods in the Black Sea rivers.

On the interannual scale, the increase of the number of inundations, and, hence, the damage involved, is implicit. It is mainly caused by an appreciable increase of the number of inundations in the period from the early 1970s until the early years of the twenty-first century. The main reason is found in a changing climate but another influence, especially regarding the extreme inundations, is anthropogenic influences such as irrational and badly planned economic activities in channels, flooded terrains and on river watersheds. The mean annual frequency of inundations and dangerous floods on the entire coast is about once in 0.3 years. The number of inundations in the region varies with a duration of cycles from 6-7 to $10-12$ years.

Not all administrative areas of the coast are equally at risk and vulnerable to river inundations. The most dangerous areas are the Novorossiysk, Gelendzhik, Tuapse and Sochi municipal districts. The larger Sochi area is in danger of a high frequency of inundations, whereas in the other three areas the high danger results from higher extremes of storm rain floods. Not surprisingly, here are more cases of catastrophic inundations and loss of human lives. In general, the total annual economic and social risk from river inundation can be approximately estimated at USD 13.3 million and two human lives at the Black Sea coast of the Russian Federation.

Our systematic analysis will increase awareness of the public to raise the level of safety and security of the terrain, and objects and population in the Black Sea Coast area not only by improving engineering actions, but also by the optimization of the terrain, and the increase of system effectiveness of the monitoring and forecasting critical hydrometeorological situations, resulting in improved early danger warnings.

Acknowledgements. The authors are grateful for the support of their database collections, field investigations, and hazard estimations as members of the Natural Risk Assessment Laboratory (NRAL) of Lomonosov Moscow State University under grant no. 11.G34.31.0007. Analysis of floods characteristics, features and regularities of flood routing, and mapping of flooding zones were financially supported by the Russian Science Foundation (grant no. 14-17-00155). Part of the research related to the analysis of synoptic conditions was supported by grant RFBR 13-05-41058. Inundation typification, methodology of flood cases identification based on hydrometeorological data and the design of countermeasures were developed as part of the grant of the Russian Science Foundation (grant no. 14-37-00038).
The authors gratefully acknowledge the careful attention and suggestions of Sven Fuchs and an anonymous referee, which led to a significant improvement of the paper.

Edited by: I. Didenkulova

Reviewed by: S. Fuchs and one anonymous referee

\section{References}

Alexeevsky, N. I. and Magritsky, D. V.: Methods of research and assessments of the dangerous hydrological phenomena in the mouths of the rivers, The Mouths of the rivers of the Caspian region: formation history, modern hydrological-morphological processes and the dangerous hydrological phenomena, Publishing house GEOS, Moscow, 38-50, 2013.

Alexeevsky, N. I., Magritsky, D. V., Reteyum, K. F., and Yumina, N. M.: Scientific backgrounds of the structure and the contents of the database for studying of processes of flooding of the mastered areas, Proceedings of the All-Russia scientific conference, Publishing house LIK, Novocherkassk, 17-23, 2013.

Arkhipkin, V. S., Dobrolubov, S. A., Mukhametov, S. S., Nedospasov, A. A., Samborski, T. V., Samsonov, T. E, Serebrennikova, E. A., and Surkova, G. V.: Extreme rain flooding in the basin. Ashamba's river and its impact on the bottom topography and the structure of the sea waters near Gelendzhik, Vestnik Moskovskogo Unviersiteta, Seriya Geografiya, 3, 27-34, 2013.

Atlas of connatural and technogenic dangers and risks of emergencies of the Southern Federal district, Publishing house Moscow Press, 384 pp., 2007.

Barinov, A. J.: Geomorphological assessment of rainstorm mudflow hazard of the Black Sea coast, the Autor's abstract of the PhD dissertation, Moscow, 2009.

Baselyuk, A. A.: The dangerous hydrometeorological phenomena in the south of the European terrain of Russia, Connatural and social hazards in the coastal region of the Black and Azov Seas, Publishing house Triumph, Moscow, 33-41, 2012.

Belyakova, P. A, Borshch, S. V., Khristoforov, A. V., and Yumina, N. M.: Forecasting of the maximum flow of the rivers of the Black Sea coast of Krasnodar territory, Water Manage., 6, 4-16, 2013.

Berlin, S. I. and Petrov, D. V.: Strategic prospects of the travel industry development in the Krasnodar krai, Theory and practice of Social Development, Int. Sci. J., 20, 78-83, 2015.

Data of Federal State Statistics Service in Krasnodar region, http://krsdstat.gks.ru/wps/wcm/connect/rosstat_ts/krsdstat/ ru/statistics/, last access: 17 May 2014.

Dobroumov, B. M. and Tumanovsky, S. M.: Inundations on the rivers of Russia: their formation and division into districts, Russ. Meteorol. Hydrol., 12, 70-78, 2002.

Dobrovolsky, S. G. and Istomina, M. N.: World inundations, Publishing house GEOS press, Moscow, 256 pp., 2006.

Dzerdzeevskiy, B. L.: The general circulation of atmosphere and the climate. Selected works, Publishing house Science, Moscow, 287 pp., 1975.

Ermachkov, I. A.: To the question on emergencies in terrain of the Big Sochi in the time of the rearrangement (1985-1991), Former years, 3, 57-60, 2010. 
Evsyukov, J. D., Rudnev, V. I, Kuklev, S. B., and Hvoroshch, A. B.: The valley of the Ashamba river and the Golubaya Buhta after an inundation in the northeast of the Black sea coast, Geol. Search. Oil Gas Invest., 1, 9-17, 2013.

Fujita, T. T.: Tornadoes and downbursts in the context of generalized planetary scales, J. Atmos. Sci., 38, 1511-1534, 1981.

Kononova, N. K.: Circulation of atmosphere as the factor of nature hazards in the North Caucasus in the XXIst century, Geopol. Ecodyn. Reg., 8, 72-103, 2012.

Ligda, M. G.: Radar storm observation, in: Compendium of Meteorology, edited by: Malone, T. F., Boston, Am. Meteor. Soci., 1265-1282, 1951.

Magritsky, D. V., Alexeevsky, N. I., Krylenko, I. N., Yumina, N. M., Efremova, N. A., and Shkolny, D. I.: Risks of inundations in lower reaches and mouths of the rivers of the Black Sea coast of Russia, Proceedings of the All-Russia scientific conference, Publishing house LIK, Novocherkassk, 181-187, $2013 \mathrm{a}$.

Magritsky, D. V., Samokhin, M. A., and Yumina, N. M.: Inundations at the Krasnodar territory and the republic of Adygea, Sci. Tech. Technol., 4, 44-63, 2013b.

Malik, L. K.: The cause and consequences of inundations, Safety of power constructions, 11, Publishing house NIIES, Moscow, 50-75, 2003.

Markowsky, P. and Richardson, Y.: Mesoscale Meteorology in Midlattitude, Penn State University, USA, 417 pp., 2002.

Matveeva, T. A., Gushchina, D. J., and Koltermann, K. P.: Factors of catastrophic inundations in the river mouths of the European part of Russia, Moscow University Bulletin, Series 5: Geography, 2, 70-77, 2013.

Nezhihovsky, R. A.: Inundations on the rivers and lakes, Gydrometeoizdat Publishing house, Leningrad, 184 pp., 1988.

Orlanski, I.: A rational subdivision of scales for atmospheric processes. Bull. Amer. Meteor. Soc., 56, 527-530, 1975.

Panov, V. D., Bazelyuk, A. A., and Lurje, P. M.: Rivers of the Black Sea coast of The Caucasus: Hydrography and the regime of flow, Rostov-on-Don: the Don publishing house, 605 pp., 2012.
Petrakov, D. A., Tutubalina, O. V., Aleinikov, A. A., Chernomorets, S. S., Evans, S. G., Kidyaeva, V. M., Krylenko, I. N., Norin, S. V., Shakhmina, M. S., and Seynova, I. B.: Monitoring of Bashkara glacier lakes (Central Caucasus, Russia) and modelling of their potential outburst, Nat. Hazards, 61, 1293-1316, 2012.

Rasmussen, E. A. and Turner, J.: Polar lows. Mesoscale Weather Systems in the polar region, Cambridge Press, 612 pp., 2003.

Resources of surface water of the USSR, Volume 9 (1). Gydrometeoizdat Publishing house, Leningrad, 310 pp., 1969.

Sergin, S. J., Jajli, E. A., Tsai, S. N., and Potekhina, I. A.: Climate and wildlife management of the Krasnodar Black Sea Coast. Publishing house RGGMU, Sankt-Petersburg, 265 pp., 2001.

Svanidze, G. G. and Tsutskeridze, J. A. (Ed.): Dangerous hydrometeorological phenomena on the Caucasus, Gydrometeoizdat Publishing house, Leningrad, 265 pp., 1983.

Taratutin, A. A.: Inundations on the territory of the Russian Federation, Publishing house RosNIIVH, Ekaterinburg, 376 pp., 2000.

Taratutin, A. A.: Inundations on the continents and in the World countries, edited by: Koronkevich, N. I., Publishing house RosNIIVH, Ekaterinburg, 480 pp., 2011.

Tkachenko, J. J.: Dangerous hydrometeorological phenomena at the Black Sea coast related to heavy rainfalls, Connatural and social risks in the coastal region of The Black and Azov Seas. Publishing house Triumph, Moscow, 43-46, 2012.

Volosuhin, V. A and Tkachenko, J. J.: Forecasting of parameters of floods on the rivers of Krasnodar territory, Hydraulic engineering, 4, 16-20, 2013.

Vorobyev, J. L.: Catastrophic inundations of the beginning of the XXI century. Publishing house Decks-press, 352 pp., 2003.

Zemtsov, S. P., Baburin, V. L., Koltermann, K. P., Krylenko, I. N., Yumina, N. M., and Litvinov, V. Y.: Social risk and vulnerability assessment of the hazardous hydrological phenomena in the Krasnodar region of Russia, Geogr. Environ. Sustain., 7, 95-118, 2014. 